Portland State University

PDXScholar

5-30-1996

\title{
Temperament Differences in Children with a History of Slow Expressive Language Development and Their Peers with Normal Language Development
}

Beth Ann Jones

Portland State University

Follow this and additional works at: https://pdxscholar.library.pdx.edu/open_access_etds

Part of the Speech and Rhetorical Studies Commons

Let us know how access to this document benefits you.

\section{Recommended Citation}

Jones, Beth Ann, "Temperament Differences in Children with a History of Slow Expressive Language Development and Their Peers with Normal Language Development" (1996). Dissertations and Theses. Paper 5281.

https://doi.org/10.15760/etd.7154

This Thesis is brought to you for free and open access. It has been accepted for inclusion in Dissertations and Theses by an authorized administrator of PDXScholar. Please contact us if we can make this document more accessible: pdxscholar@pdx.edu. 


\section{THESIS APPROVAL}

The abstract and thesis of Beth Ann Jones for the Master of Science in Speech Communication: Speech and Hearing Science were presented May 30, 1996, and accepted by the thesis committee and the department.

COMMITTEE APPROVALS:

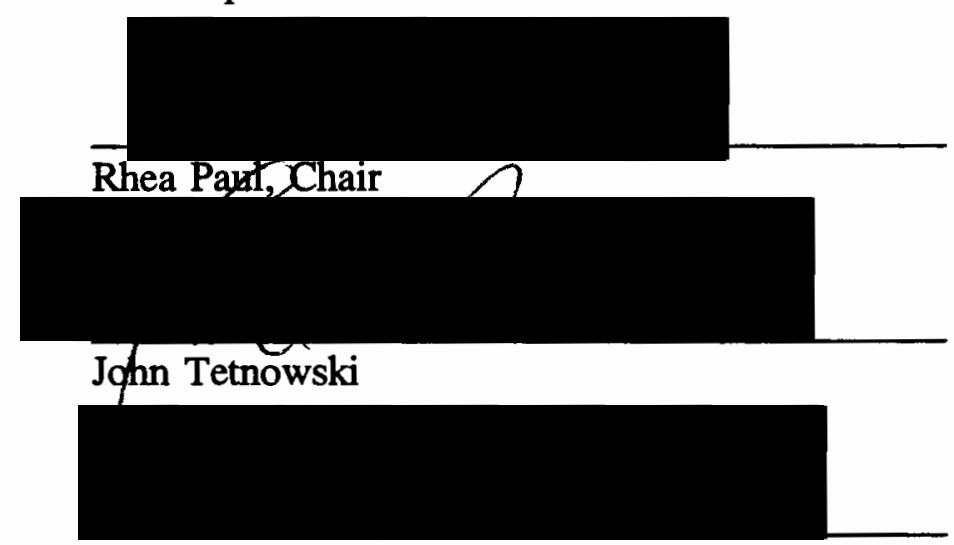

Dean Frost

Representative of the Office of Graduate Studies

DEPARTMENT APPROVAL:

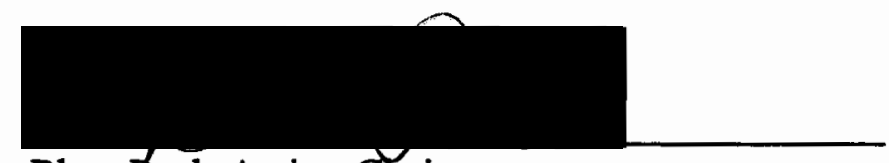

Rhea Paul, Acting Chair

Department of Speech Communication

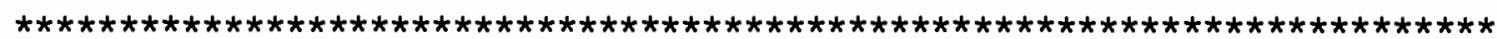

ACCEPTED FOR PORTLAND STATE UNIVERSITY BY THE LIBRARY

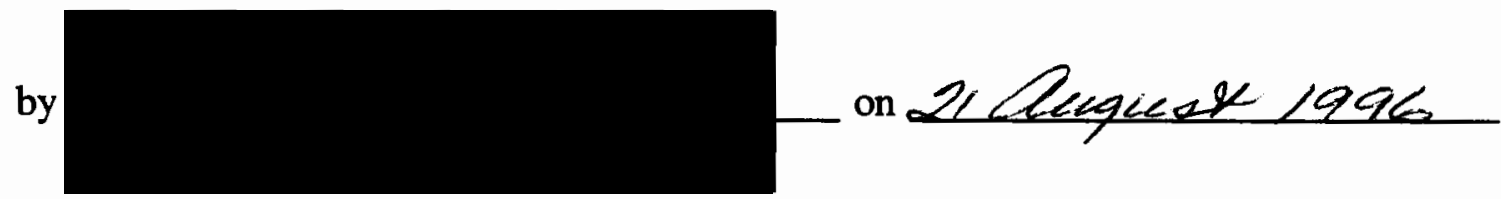




\begin{abstract}
An abstract of the thesis of Beth Ann Jones for the Master of Science in Speech Communication: Speech and Hearing Science presented May 30, 1996.
\end{abstract}

Title: Temperament Differences in Children with a History of Slow Expressive Language Development and Their Peers with Normal Language Development.

Language is the way in which individuals are able to express ideas, feelings, needs, expectations, and form relationships with others in their surrounding environment. A disruption in language development may negatively impact a child's social development. Research shows that children with language delays or disorders tend to have increased social and behavioral difficulties (Cantwell \& Baker, 1977; Caulfield, Fischel, DeBaryshe, \& Whitehurst, 1989). However, research has not examined temperament differences in young children with language delays or disorders.

The question this study sought to answer was: Is there a significant difference in the dimensions of temperament between children with a history of slow expressive language development and their peers with normal language development?

The subjects in this study ranged in age from 64 to 74 months. They included 33 children with a history of slow expressive language development (SELD) and 27 
children with normal language development. The temperamental characteristics of each of the subjects was assessed by ratings provided by their parents, utilizing the Parent Temperament Questionnaire for Children (Thomas, Chess, \& Korn, 1977), a questionnaire to assess the way a child behaves during everyday situations.

The question was analyzed by calculating the means and standard deviations for the nine temperament dimensions for the two groups. To determine if there were significant differences among the two groups, two tailed $t$-tests were computed at the .05 level of significance.

The Parent Temperament Questionnaire for Children (Thomas et al., 1977) showed the children with a history of slow expressive language development to have significantly different scores in the dimensions of approach-withdrawal and intensity of reaction than the subjects with normal language development at 5 years of age. 
TEMPERAMENT DIFFERENCES IN CHILDREN WITH A HISTORY OF SLOW EXPRESSIVE LANGUAGE DEVELOPMENT AND THEIR PEERS WITH NORMAL LANGUAGE DEVELOPMENT

$$
\text { by }
$$

BETH ANN JONES

A thesis submitted in partial fulfillment of the requirements for the degree of

\author{
MASTER OF SCIENCE \\ in \\ SPEECH COMMUNICATION: \\ SPEECH AND HEARING SCIENCE
}

Portland State University

1996 


\section{ACKNOWLEDGEMENTS}

I want to extend a special thanks to all those who gave me encouragement and support during the completion of this thesis.

First, I want to thank the Department of Speech and Hearing Sciences at Portland State University for accepting me into the Graduate Program. It is within this department that I have made friendships that will last a lifetime. These friends, Carla, Tracy, Tracey, Emily, and Cindy, not only provided me with support during my thesis work, but throughout the entire two years of the Master's Program.

Next, I want to thank Dr. John Tetnowski and Dr. Dean Frost for their guidance and insightful suggestions to further strengthen the findings of this study.

Importantly, I would like to express my deep thanks and gratitude to Dr. Rhea Paul for allowing me to participate in this research project. Dr. Paul has been an inspiration to me personally and professionally. I thank Dr. Paul for her guidance and her ability to share the wealth of information she possesses without reservation. 
TABLE OF CONTENTS

PAGE

CHAPTER

I INTRODUCTION AND STATEMENT OF PURPOSE $\ldots \ldots \ldots 1$

Introduction $\ldots \ldots \ldots \ldots \ldots \ldots \ldots \ldots \ldots$

Statement of Purpose $\ldots \ldots \ldots \ldots \ldots \ldots \ldots$

Definition of Terms $\ldots \ldots \ldots \ldots \ldots \ldots \ldots \ldots$

II REVIEW OF THE LITERATURE $\ldots \ldots \ldots \ldots \ldots \ldots \ldots$

Studies of Temperament $\ldots \ldots \ldots \ldots \ldots \ldots \ldots$

Additional Theories of Temperament . . . . . . . . 14

Temperament and Childhood Adjustment . . . . . . 16

Temperament and Behavior Disorders . . . . . . 18

Behavior Problems of Children with Speech and Language Impairments . . . . . . . . . . . 19

Language Delays in Behaviorally Disturbed Children . . . 23

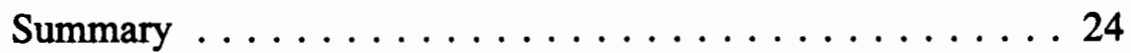

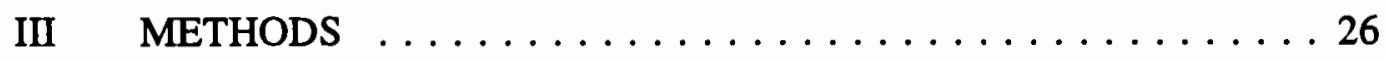

Subject Selection $\ldots \ldots \ldots \ldots \ldots \ldots \ldots \ldots$

Procedures $\ldots \ldots \ldots \ldots \ldots \ldots \ldots \ldots \ldots \ldots$

Instrument $\ldots \ldots \ldots \ldots \ldots \ldots \ldots \ldots \ldots \ldots \ldots \ldots$

Data Analysis . . . . . . . . . . . . 32 
IV RESULTS AND DISCUSSION $\ldots \ldots \ldots \ldots \ldots \ldots \ldots$

Results .................. 33

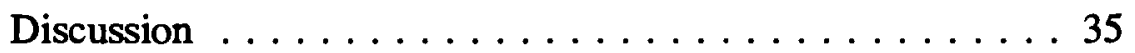

$\mathrm{V} \quad$ SUMMARY AND IMPLICATIONS $\ldots \ldots \ldots \ldots \ldots \ldots \ldots$

Summary $\ldots \ldots \ldots \ldots \ldots \ldots \ldots \ldots \ldots \ldots$

Research Implications $\ldots \ldots \ldots \ldots \ldots \ldots \ldots \ldots$

Clinical Implications $\ldots \ldots \ldots \ldots \ldots \ldots \ldots \ldots$

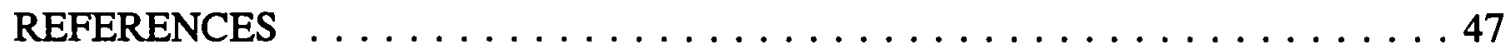

\section{APPENDICES}

A Human Subject Approval $\ldots \ldots \ldots \ldots \ldots \ldots \ldots \ldots$

B Demographic Data for Subjects $\ldots \ldots \ldots \ldots \ldots \ldots \ldots \ldots$

C Parent Temperament Questionnaire for Children $\ldots \ldots \ldots \ldots 55$

D Subject Data $\ldots \ldots \ldots \ldots \ldots \ldots \ldots \ldots \ldots \ldots \ldots \ldots \ldots \ldots \ldots$ 


\section{LIST OF TABLES}

PAGE

TABLE

1. Demographic Data for Subjects at Intake and Age 5: Means and Standard Deviations $\ldots \ldots \ldots \ldots \ldots$

2. $\quad t$-Tests Indicating Differences Between the Normal (N) and Slow Expressive Language Development (SELD) Subjects on the Parent Temperament Questionnaire for Children . . . . . . . . . . . . 34

3. Questions from the Significantly Different Temperament Dimensions on the Parent Temperament Questionnaire for Children . . . . . . . . . . . . . . . . . 36 


\section{CHAPTER I}

\section{INTRODUCTION AND STATEMENT OF PURPOSE}

\section{INTRODUCTION}

Numerous studies have investigated the differences in behavior characteristics between children with language disorders and those of their non-language disordered peers. Because language provides a child with the tool to express emotions, feelings, needs, and thoughts in order to develop relationships and participate in the social environment, language problems may affect the development of social, behavioral, and emotional skills. A significant delay in one area can be associated with developmental difficulties in other areas (Lewis, 1977). Research shows that a relationship between language and behavior exists (Baker, Cantwell, \& Mattison, 1980; Caulfield, DeBaryshe, Fischel, \& Whitehurst, 1989; Richman \& Stevenson, 1978). It seems possible then, that a childhood language disorder could affect behavior development. Many studies report that pre-school and school-aged children with language disorders are at risk for developing behavioral problems, such as attention deficit disorders, conduct disorders, being shy, and crying easily (Cantwell \& Baker, 1982; Chess, 1974; Richman \& Stevenson, 1978). Yet, research has failed to study temperament differences in young children with language delays or disorders. 
Goldsmith et al. (1987) define temperament as:

Relatively consistent, basic dispositions inherent in the person that underlie and modulate the activity, reactivity, emotionality, and sociability. Major elements of temperament are present early in life, and those elements are likely to be strongly influenced by biological factors. As development proceeds, the expression of temperament becomes more influenced by experience and context. (p. 524)

The concept of temperament has appeared in child development research within the last 30 years. Personality theorists, developmental genetics, educational researchers, and developmental psychologists have also been interested in the concept (Kohnstamm, Bates, \& Rothbart, 1989). Each discipline utilizes the concept with its own goals so that a universal consensus concerning the dimensions of the concept continues to be in debate. Nevertheless, researchers have attempted to develop an understanding of the nature of temperament. In general, temperament is used to describe the child's behavior style (Thomas \& Chess, 1977).

The emphasis on temperament has developed in part from the results of the New York Longitudinal Study (NYLS) (Thomas, Chess, Birch, Hertzig, \& Korn, 1963). The NYLS sought to uncover the interaction between environment and temperament in the development of behavior disorders (Thomas, Chess, \& Birch, 1968). From the NYLS, emerged the focus on temperament as an individualistic style of behavior referring to the how of behavior, differentiated from the why or motivation of behavior (Thomas et al., 1968). Thomas and Chess (1977) refer to temperament as the way in which an individual behaves. A group of children may possess similar motivations and abilities to perform a task or activity, but they differ as to the "intensity with which they act, the quickness with which they move, the 
intensity of expression of their mood, the ease with which they will approach a new situation, the persistence with which they maintain the activity, and the degree of distractibility required by others to disengage them when they are in the process of functioning" (Thomas \& Chess, 1977, p. 9). Temperament is judged in terms of the environmental situation in which it occurs and, thus, is an "attribute of the child that mediates the influence of the environment" (Goldsmith et al., 1987, p. 509). Thomas and Chess (1977) state that a child's temperament influences the environment as well as the beliefs and actions of the significant individuals in the child's environment.

There is extensive research regarding the relationship between behavior and emotional development, and language and speech disorders in children. It seems likely that a speech and language disorder or delay would affect the development of behavior and emotional skills. Also, temperamental factors may interact with a language disorder, so that language disordered children with one type of temperament may need a different style of interaction than those with another type of temperament. Understanding the temperamental characteristics of children with language disorders may increase the ability of parents and clinicians to interact optimally with these children and in turn facilitate language development.

\section{STATEMENT OF PURPOSE}

The purpose of this study was to determine if differences in the dimensions of temperament can be seen between 5-year-old children with a history of slow expressive language development (SELD) and their peers with normal language 
development, as indexed by parental report on the Parent Temperament Questionnaire for Children from the New York Longitudinal Study (Thomas et al., 1977).

The question this study attempted to answer is: Are there differences in the dimensions of temperament between children with a history of slow expressive language development and children with normal language development?

The hypothesis of this study is: Children with a history of slow expressive language development will score differently on The Parent Temperament Questionnaire for Children (Thomas et al., 1977) in the dimensions of temperament than children of the same age who have normal language development.

The null hypothesis is: Children with a history of slow expressive language development will not score differently on The Parent Temperament Questionnaire for Children (Thomas et al., 1977) in the dimensions of temperament than children of the same age who have normal language development.

\section{DEFINITION OF TERMS}

The following operational definitions were used for this study:

Temperament: Temperament is the biologically based, relatively stable attribute to describe the way in which an individual child behaves.

Behavior Disorders: Behavior disorders are any behaviors which are considered negative by parents and others who come into contact with the child. This includes, but is not limited to, clinically significant behavior disorders. 
Slow Expressive Language Development (SELD): In the initial stages of the Portland Language Development Project (PLDP), subjects were considered to have slow expressive language development if the child was 20-34 months old and had a vocabulary of fewer than 50 or no two-word utterances (Paul, 1991). Subjects initially identified as having slow expressive language development were also in the SELD group in this study.

Normal Language Development: In the initial stages of the Portland Language Development Project (PLDP), subjects were considered to have normally developing language if the child was $20-34$ months old and had a vocabulary of more than 50 words and used two-word combinations (Paul, 1991). Subjects initially identified as normal were also in the normal (i.e., control) group in this study.

The following terms were defined according to the Parent Temperament Questionnaire for Children (Thomas et al., 1977).

Activity Level: The child's motor activity during daily routines and during sleep-wake cycles.

Rhythmicity: The regularity of the child's vegetative functions.

Adaptability: The child's ease of transition to altered or new situations Approach-Withdrawal: The child's initial positive or negative reaction to approach or withdrawal from a new stimuli, person, or object.

Threshold of Responsiveness: The child's level of sensory stimulus required to evoke a response. 
Intensity of Reaction: The child's degree or energy of response, regardless of its direction or quality.

Quality of Mood: The child's degree of positive or negative affect.

Distractibility: The effectiveness of stimuli to alter the child's ongoing behavior.

Attention Span and Persistence: The degree to which the child's interest is maintained or activity is pursued in view of obstacles. 


\section{CHAPTER II}

\section{REVIEW OF THE LITERATURE}

Researchers have developed different hypotheses and theories to define temperament. Included are the theories of Thomas, Chess, and Birch (1968), Buss and Plomin (1984), and Rothbart (1981).

\section{STUDIES OF TEMPERAMENT}

Thomas, Chess, and Birch (1968) are considered the pioneers of temperament research, creating a wealth of information from which other research has followed. They define temperament as the way an individual behaves or a behavioral style. Temperament is a separate and independent psychological attribute similar to cognition, arousal, and motivation. Temperament interacts with these attributes in an equally influential manner over time (Thomas et al., 1968). A child who is attached to his mother might do so because he is fearful of separation (motivation), because immature motoric abilities inhibit him from age-appropriate play with peers (abilities), or because he develops negative withdrawal responses to novel situations (temperament) (Goldsmith et al., 1987). It follows that temperament is the interaction between an individual's motivation, abilities, and environment (Thomas \& Chess, 1977). Temperament is a psychological attribute of an individual which regulates environmental affects. The environment or social context can only function to 
intensify or minimize a child's expression of temperament, not change the temperamental pattern. Thus, temperament influences the effects of environmental influences and at the same time affects the judgments, behavior, and attitudes of significant others within the child's environment.

Thomas et al. (1968) examined the interaction between temperament and environment in the development of behavior disorders with the data obtained from their New York Longitudinal Study (NYLS). The NYLS began in 1956 and included 85 families. The mothers ranged in age from 20 to 41 years with the fathers' median age was at 33.6 years. Forty percent of the mothers and $60 \%$ of the fathers had a college degree and fewer than $10 \%$ of the parents had not received a college education. One hundred thirty-six children, 69 males and 67 females between the ages of 4 and 12 years of age, participated in the investigation. The socioeconomic status of the families was middle- or upper-middle class. The families' parental attitudes and child-rearing practices showed significant homogeneity. Variations in the patterns of parental child-care practices and temperament in the children enabled the researchers to examine differing interactions. Data were obtained through parent and teacher interviews and direct observations of the child's behavioral characteristics, responses, and reactions in routine and novel situations. Validity, objectivity, and reliability of data collection of the child's behavior characteristics was maintained through detailed and descriptive report of what the child did and how the child behaved, and initial and long-term recordings of the child's response to new stimuli, demands, and 
situations. Research staff members collected data for different children at different phases of the study.

Thomas et al. (1968) developed nine categories of temperament using the parental reports of the 85 subjects studied. The categories chosen were based on the criterion that the categories should be present in all the children and should appear to influence the child's psychological development. The nine categories and definitions are:

1. Activity level: The level, frequency, and tempo of a motor component of a child was utilized in scoring this category. Behavior concerned with motility was assessed during bathing, eating, sleep-wake cycles, crawling, and walking.

2. Rhythmicity: The regular and irregular patterns of biological functions were used in scoring this category. Information was analyzed in relation to sleep-wake cycles, appetite, feeding, and bowel and bladder regularity. Regular functioning is evident if an established pattern of functioning occurs with occasional deviation and irregular functioning is demonstrated by an inconsistent pattern of functioning.

3. Adaptability: The response to a novel stimuli or altered situation over time. Adaptive behavior is displayed when a child no longer spits out a food but takes it or was still during bathing and now splashes and plays in the water. Nonadaptive behavior is evident when a child resists getting a diaper changed and now screams at the sight of a diaper or the child turns his head and will not eat fruit any way it is prepared. 
4. Approach or withdrawal: The initial reaction to approach or withdrawal from a stimuli, person, or object. Approach responses are displayed by mood (e.g., smiling, verbalizations) and motor activity (e.g., playing with a new toy, accepting a new food). Withdrawal reactions are demonstrated by mood (e.g., fussing, crying) and motor activity (e.g., resisting an embrace, pushing away a new toy).

5. Threshold of responsiveness: The intensity level of external stimulation necessary to evoke a discernible response, regardless of the quality of response or affected sensory modality. A child who loves crackers until peanut butter is on them is considered to have a low threshold response with taste discrimination. A child who begins a new school and immediately interacts with the other children and never cries is illustrating a high threshold for social situations.

6. Intensity reaction: The energy with which a response is produced, regardless of its direction or quality. Intense responses are illustrated in relation to new foods, hunger, external stimuli, attempts to diaper, dress, bathe, and play and social contacts. An intense reaction is exhibited when a child laughs and jumps around when playing with a favorite toy or screams loud and long when another child takes a toy and is not distracted after regaining the toy. A mild response is displayed when a child whimpers after being taken to bed but is comforted by a blanket or when a child is full yet holds the bottle in his mouth without removing it.

7. Quality of mood: The quantity of pleasant, friendly, joyful behavior as opposed to unpleasant, unfriendly, crying behavior. Positive mood is displayed when a child always smiles and laughs and if it is not, it is an indicator the child is getting 
sick. Negative mood is illustrated when a child cries for long periods before going to sleep or continually hits other children without reason.

8. Distractibility: The effect of external environmental stimuli altering or interfering with the direction of an ongoing behavior. A child would be considered distractible when a toy prevents the child from dumping out the contents of a drawer. A nondistractible child will cry when hungry and continue, even with attempts to soothe the child, until fed.

9. Attention span and persistence: The length of time a child pursues and continues a self-initiated or planned activity when faced with internal and external obstacles. A child with a long attention span may be engaged in play for half an hour as opposed to a child with a short attention span, engaged in this play for only 5 minutes. A persistent child would attempt to walk even though he continually falls down in contrast to a child who rejects a toy because he is unable to operate it.

Three temperamental constellations were developed by Thomas et al. (1968) analyzing the behavior characteristics of the overall sample of children. The first group is characterized by attributes which include irregular biological functions, slow or nonadaptability to environmental changes, negative withdrawal responses to novel stimuli, and predominantly negative and intense mood expressions. These difficult children display irregular feeding and sleeping routines; extended or long periods of time to adapt to new situations, people, or routines; slow acceptance or withdrawal of objects, people, or situations; frequent crying or fussing; and intense reactions, such as violent tantrums or roaring laughter. The child's mood expressions occur in an all 
or nothing response without modulation. This group of children comprised approximately $10 \%$ of the NYLS sample (Thomas \& Chess, 1977).

The second group consisted of children with regular biological functions, rapidly adaptability, positive approach responses to novel stimuli, and positive in mood with low or mild levels of intensity (Thomas et al., 1968). These easy children develop regular feeding and sleeping routines; rapidly adapt to new situations, people, or routines; approach objects, people, or situations easily; often smile and laugh; and accept frustration with little resistance. These children are susceptible to behavior problems if the parental and external demands are in extreme and acute conflict with the child's temperamental attributes. Approximately $40 \%$ of the NYLS sample consisted of this group (Thomas \& Chess, 1977).

The third temperamental constellation is characterized by a combination of negative responses of low intensity to new situations with slow adaptability after repeated exposure (Thomas et al., 1968). These slow-to-warm-up children show less irregularity in biological functions, initial withdrawal reactions with slow adaptability, and positive and negative reactions with mild intensity. In the event of a behavior problem, there may be a shift to more intense negative reactions. This group comprised approximately $15 \%$ of the NYLS sample (Thomas \& Chess, 1977).

According to Thomas and Chess (1977) most children do not fit into one temperamental group, due to the variations and the degree to which different combinations of temperamental attributes are manifested in children. A child may show difficult, easy, and slow-to-warm-up temperament, have a high to low activity 
level, positive and negative intensity of reaction, and represent other extreme variations. The combination and range of behavior styles are not indicative of a psychopathology, but displayed by normally developing children. Thomas et al. (1968) also identified certain temperamental traits and constellations which have been frequently associated with behavior disorders. The combination of "irregularity, nonadaptability, withdrawal responses, and predominantly negative mood of high intensity; the combination of withdrawal and negative responses of low intensity to new situations, followed by slow adaptability; excessive persistence; excessive distractibility; and markedly high or low activity level" (Thomas et al., 1968, p. 71) were represented by the children in the NYLS with behavior disorders. Yet, "for a given temperamental pattern to contribute to the development of a behavioral disturbance, it requires particular kinds of interaction between the child with the temperamental pattern and his effective environment" (Thomas et al., 1968, p. 71). A poorness of fit involves dissonance between the child's environment and temperamental patterns, facilitating distorted development and maladaptive behavior. A goodness of fit occurs when a consonance exists between the environmental demands and the child's temperament pattern, promoting optimal and positive development. Thomas and Chess (1977) suggest that temperament is one of several variables which may contribute to the development of behavior disorders. 


\section{ADDITIONAL THEORIES OF TEMPERAMENT}

Buss and Plomin (1984) define temperament as early-appearing personality traits, present in infancy and childhood, that are inherited. Three specific traits comprise temperament: emotionality, activity, and sociability (EAS). Emotionality refers to distress, varying from high-arousal states that are out of control to low-arousal states lacking emotion. Activity is composed of tempo and vigor. Activity is measured according to the rate, duration, frequency, and amplitude of the response. A child will vary from lethargic to hyperactive states of activity. Activity involves behavioral arousal as differentiated from the physiological arousal of emotionality. Sociability is the preference to initiate and maintain contact with others as opposed to being alone. A continuum exists in the need to be with others, changing with time and situation. Sociability is measured according to the number of attempts made to initiate contact, the number of people sharing an activity, the amount of time spent in the presence of others, reactions to isolation, and mutual responsivity. Buss and Plomin (1984) state that these three traits tend to have strong genetic components, suggesting they will display stability over time. Yet, the traits are expected to be influenced by the environment and developmental events. These early-developing traits originate from biological influences and changes in the mean levels of temperament are expected as a result of childhood events. The researchers emphasize the role of the individual in selecting or altering an environment to match or mismatch their set of personality traits. As an example, a child who is highly social will be most comfortable when playing with others, creating a match between the 
child and his environment. A conflict is likely to occur between a child and parent who are both high in emotionality.

Rothbart (1981) defines temperament as the biological, stable, and constitutional differences in reactivity and self-regulation. Constitutional refers to the biological differences of individuals, affected over time by heredity, maturation, and experience. Reactivity is the arousal of motor activity, affect, autonomic, and endocrine responses, as evidenced by a child who bangs a toy to release motor tension. Self-regulation serves to facilitate or inhibit reactivity by the processes of attention, withdrawal, avoidance, approach, inhibition, and behavior, as evidenced by a child who withdrawals in the presence of a stranger. Behaviorally, temperament can be observed in individual differences of emotion, attention, and motor activity. According to Rothbart (1981), the dimensions of temperament include negative reactivity, reflected in internal and external distress and behavioral and attentional aversion, such as fear. Positive reactivity is reflected in internal and external affect and behavioral and attentional approach, as evidence by smiling, laughing, and attending to objects. The infant is viewed as a "model system" for the study of temperament, allowing investigators to observe the processes of its development before environmental interactions facilitate or inhibit positive or negative reactions (Rothbart, 1981). According to Rothbart (1981), the developmental nature of temperament suggests that periods of stability and discontinuity will occur, as is true with the development of intelligence. Temperament may appear relatively stable and at the same time transform with maturation. Individual variability dictates the time at 
which these characteristics will appear. Rothbart (1981) suggests that the extent to which temperament will be influenced by the environment is dependent on the degree of stimulation, the individual's reaction to that stimulation, and the strategies utilized to deal with the stimulation.

\section{TEMPERAMENT AND CHILDHOOD ADJUSTMENT}

The classroom may be the first socialization experience outside the home for many children. Children's success within this setting is dependent on intellectual abilities and motivation and greatly influenced by their ability to initiate and maintain peer and adult relationships. An influential factor linked to the development of social interactions is temperament (Skarpness \& Carson, 1986). In 1993, Jewsuwan, Luster, and Kostelnik investigated children's temperamental attributes and their preschool adjustment. Temperament of 35 children between the ages of 36 to 60 months was analyzed. Temperament characteristics were assessed by parent ratings on the Colorado Childhood Temperament Inventory (CCTI) and teacher ratings on the CCTI, Behar's Preschool Behavior Questionnaire (PBQ), and the Preschool Adjustment Questionnaire (PAQ). Children perceived as less well adjusted by their parents received scores high in emotionality and activity and low scores in sociability. Children with high scores in emotionality were perceived by teachers to be less well adjusted. Children with high activity ratings showed more behavior problems as reported by teachers. Well adjusted children received high scores in sociability and low scores in emotionality and activity level from their parents. Children with high 
sociable scores and low emotional scores were perceived by teachers as being well adjusted.

Scholom, Zucker, and Stollak (1979) further investigated the relationship between temperament and child adjustment. Subjects included 132 children between 3 and 4 years of age. Temperament characteristics were identified through parent and teacher report on the Carey Infant Temperament Survey (CITS), the Thomdike Dimensions of Temperament Measure (TDOT), and the Stollak Temperament Survey (STS). High mood scores and low energy scores were the most significant factors in child adjustment reported by teachers. Parents rated mood, energy, and consistency as the temperament characteristics related to child adjustment at 4 years of age.

Mobley and Pullis (1991) reported childhood temperament ratings associated with child behavior adjustment. The subjects were 44 preschool children ages 3 to 4 and their teachers. Teachers were provided with the Teacher Temperament Questionnaire short form (TTQ-SF) to rate child temperament and the Rochester Adaptive Behavioral Inventory (RABI) to assess social-emotional competence of the child. Less cooperative and more active children were rated highest in reactivity. These children showed atypical behavior, displaying difficulty with self-reliance, initiative, persistence, and self-control. High task orientation, personal-social flexibility, and low reactivity were related to positive adjustment in preschool. 


\section{TEMPERAMENT AND BEHAVIOR DISORDERS}

Studies have found that certain temperamental attributes may play a role in the development of behavior disorders. Mehregany (1991) investigated the temperamental characteristics of a sample of 55 , clinically referred 3 to 6 year old children, related to behavior disorders. The Behavior Screening Questionnaire (BSQ) and Dimensions of Temperament Survey (DOTS) was completed by the parents about their child. A low score on the BSQ showed low activity levels and distractibility with high rhythmicity. A high score on the BSQ with high activity levels and distractibility and low rhythmicity was associated with a high degree of psychopathology.

A study by Fagot and O'Brien (1994) reported the levels of motor activity and other dimensions of temperament correlated with behavior disorders. The subjects consisted of 49 children with an average age of 4 years, 5 months. Play observations and data obtained from the Behavioral Style Questionnaire were utilized to assess the children's activity levels and temperamental characteristics. Distractibility was significantly associated with activity levels for the entire sample. Boys with high activity levels at home or school were rated as having more behavior problems.

In 1980, Terestman examined the mood and intensity temperament characteristics of 58 children between the ages of 3 and 5 years. The subjects were divided into two groups: 27 children were included in the clinical group, diagnosed by a clinical psychiatrist as exhibiting deviant or difficult behavior, and 31 children were in the nonclinical group. Teacher interview and direct observation were scored according to the criteria of the NYLS (Thomas et al., 1963). Data found that 14 of 
the 15 children (93\%) with negative mood and 13 of the 15 children (87\%) with high intensity were in the clinical group.

A relationship exists between temperament and behavior, where temperament determines how a behavior is performed (e.g., crying expressed intensely vs. moderately or in quick vs. slow reaction). Bates (1990) views temperament as a pattern in observed behavior. Graham, Rutter, and George (1973) conducted an extensive review of temperament characteristics and behavior disorders and concluded that the 26 out of 60 children with behavior disorders were "significantly more negative in mood and less regular in biological functioning" (p. 333-334).

Studies have investigated the relationship between children with language delays and behavior disorders. Cantwell and Baker (1977) reviewed the literature and found a higher incidence of psychiatric disorders in children with speech and language disorders than their peers with normal language development. Behavior disorders in children may provide the link to further understanding the temperament characteristics present in children with language delays.

\section{BEHAVIOR PROBLEMS OF CHILDREN WITH SPEECH AND LANGUAGE IMPAIRMENTS}

The association between children with language disorders and behavior disorders has been studied extensively. Orton (1937) observed that any disorder affecting the ability to communicate would lead to secondary behavior deficits. The validity of this statement continues to be true in a number of different research studies. 
A number of studies have indicated that children with speech and language disorders are more likely to develop behavior difficulties than their peers with normal language development. Baker, Cantwell, and Mattison (1980) investigated behavior problems in children with speech and language disorders. The behavior of 53 children with speech and language deficits was analyzed. Behavior disorders were identified through parent and teacher evaluation on the Conners Parent and Teacher Questionnaires and the Rutter Parent and Teacher Questionnaires. The parents and teachers rated hyperactivity syndrome (e.g., excessive motor activity, impulsivity, mood changes, nervous tics and mannerisms, odd noises, and easily distractible), developmental phenomena (e.g., bed wetting, crying, parental attachment, and baby talk), conduct disorder (e.g., antisocial behaviors and disobedience), relationships (e.g., fights with siblings), emotional complaints (e.g., fear of new situations and people, being alone and worried, miserable, overly sensitive, and distressed), miscellaneous problems (e.g., tantrums, irritability, daydreaming, not obeying rules, and/or not learning at school) as the most severe behavioral symptoms.

In 1982, Baker and Cantwell conducted further studies of behavioral disorders in children with speech and language deficits. Subjects consisted of 180 children with speech and/or language disorders. A questionnaire by Rutter and Conners was provided to parents and teachers to assess the child's behavioral problems. Parents of $33 \%$ of the subjects reported their feelings were easily hurt, $28 \%$ were easily frustrated, $19 \%$ had short attention spans, and $16 \%$ had wetting problems. Teachers reported mood changes, solitary behavior, defiance, demands for attention, fidgeting, 
and stubbornness for the speech and/or language delayed children. A psychiatric diagnosis was determined for $53 \%$ of the children in the study, according to the Diagnostic and Statistical Manual of Mental Disorders (DSM-III) (The American Psychiatric Association, 1980). Attention deficit disorder was the most common, occurring in $16 \%$ of the children. Oppositional and avoidant disorders were the second most common psychiatric disorder in $6 \%$ of the children.

Chess (1974) reported the type and frequency of speech disorders of children in one private practice. A 3-year period of children's clinical records revealed that out of 563 children, $139(24 \%)$ had a language deficit. The most frequently occurring types of deficits were delayed onset or slow development of speech, articulation disorders, use of echolalia or jargon, and stuttering. They found that parents of $19 \%$ of the 139 subjects with speech disorders reported behavior difficulties, including tantrums, disruptive behavior, poor peer relations, discipline problems, withdrawn behavior, and separation anxiety. Hyperactivity was present in $26(19 \%)$ of the children. It must be noted that of the 139 children, 37 were diagnosed with cerebral dysfunction (i.e., neurological impairment or mental retardation), 28 with developmental lag (i.e., developmental aphasia or central language impairment), 28 with a differential diagnosis (i.e., further study was necessary to determine a diagnosis), 22 with reactive behavior (i.e., behavior deviations reactive to environmental stress and reversible with removal of stimulus), 16 with thought disorder (i.e., poor reality-perception, confused ideation, and gross disturbance in 
relatedness), and 8 with neurotic behavior disorder (i.e., inappropriate internalized attitudes).

Researchers have suggested that children with language disorders have significantly more behavior, emotional, and temperament difficulties than children with normal language development. Richman and Stevenson (1978) conducted an epidemiological study of behavior, language, and development with a random sample of 705, 3-year-old children. A developmental assessment of expressive and receptive language skills identified 24 children as language delayed. A Behavior Screening Questionnaire identified behavior problems in 101 children in the sample. Richman and Stevenson (1978) found that of the children with expressive language delay, $59.1 \%$ had behavior problems. This is significant because data revealed that only $14.3 \%$ of the random sample displayed behavior problems. In addition, $12.9 \%$ of the children with behavior problems were language delayed, compared to $3.1 \%$ of the total sample who were language delayed.

Caulfield et al. (1989) examined behavior correlates of children with expressive language disorders. The subjects were 34 normally developing children and 34 children with expressive language delay. The children were identified with an expressive language delay if they scored at least 2.5 standard deviations below the mean on the Expressive One-Word Picture Vocabulary Test-Revised and one standard deviation below the mean on the Peabody Picture Vocabulary Test-Revised. The Eyeberg Child Behavior Inventory compared the behavior between the children with expressive language delay and children with normal language development. The 
data found that the language delayed group had a higher rate of negative behavior than the control group with normal language development. The type of problems they found were with parental control, mood changes, sibling relationships, and physical contact.

\section{LANGUAGE DELAYS IN BEHAVIORALLY DISTURBED CHILDREN}

Other researchers have investigated language delays of emotionally handicapped children in guidance centers and public schools. Gidden, Jurs, \& Trautman (1990) conducted a study of language risk factors in behaviorally-emotionally disturbed children in a day treatment program. The 67 subjects studied were admitted to the program because of severe behavioral and emotional difficulties. Each subject was diagnosed with a specific psychiatric disorder, according to the Diagnostic and Statistical Manual of Mental Disorders (DSM-III) (American Psychiatric Association, 1980). The Clinical Evaluation of Language Function-Diagnostic Battery (CELF) and the Test of Language Development (TOLD) was utilized to assess the subjects' expressive and receptive language performance. The test results found that 36 of the 67 children (54\%) had a speech and/or language disorder. The children with Pervasive Development Disorders, Attention Deficit Disorders, and Conduct Disorders, all had identifiable language disorders.

Camarata, Hughes, and Ruhl (1992) conducted a study to examine the language skills of mild/moderate behavior disordered students in a public school. 
Included in the study were 30 children and adolescents identified as emotionally disturbed who were mainstreamed within a regular classroom for one or more courses (Camarata, Hughes, and Ruhl, 1992). Subjects ranged from second through tenth graders. The Test of Language Development-Intermediate (TOLD-I), the Test for Auditory Comprehension of Language-Revised (TACL-R), the Peabody Picture Vocabulary Test-Revised (PPVT-R), and the Expressive One-Word Vocabulary Test (EOWVT) were used to assess the behavior disordered students' language development. The test results revealed that the subjects' standard scores fell one standard deviation below the mean on all measures, except for the Word Classes and Relations subtest of the TACL-R.

\section{SUMMARY}

In surveying the literature it is apparent that children with language delays are at risk for developing maladaptive behaviors and certain temperamental attributes are linked to the development of behavior disorders in young children. Temperamental characteristics which play a role in the development of behavior disorders may be found in young language delayed or disordered children. However, while much is known about behavior problems of children with language delays or disorders, no research has focused strictly on the temperamental characteristics of children with language delays or disorders.

The results of studies indicate that children with language disorders have a higher prevalence of behavior and emotional difficulties. However, little is known 
about temperament as a dimension of behavior for language delayed or disordered young children. The importance of addressing the relationship between language delays or disorders and aspects of temperament in the initial stages of language development should not be overlooked. Temperament research may help to solve the problems of the relationship between language disorders and behavior difficulties.

A study focusing on temperament characteristics of language delayed or disordered children should be completed. It may provide further insight into the development of language disorders. If nothing more, it may assist the speech-language pathologist in determining which areas to asses in language disordered children. 


\section{CHAPTER III}

\section{METHODS}

\section{SUBJECT SELECTION}

Two groups of subjects will be used in this study: children with a history of slow expressive language development and normal language development. The subjects will be selected from the Portland Language Development Project (PLDP), a longitudinal study by Paul (1991) following children with slow expressive language development (SELD) (see Table 1). The subjects of the PLDP were recruited by radio and newspaper advertisements and referrals from local pediatric clinics. The slow expressive language development group consisted of 33 children between ages 20 and 34 months. The PLDP defined slow expressive language development (SELD) as producing fewer than 50 words at 20-34 months (Paul, 1991). Parents utilized the Language Development Survey (LDS) (Rescorla, 1989) to report their child's expressive vocabulary. The normal language subjects consisted of 27 children matched to the language delayed group by age, socioeconomic status (SES), race, birth order, and sex. The children were chosen for the normal language group because their language exceeded the criterion of 50 words outlined on the Language Development Survey (LDS) at 20-34 months. The average age in the group with slow expressive language development was 25.4 with a standard deviation of 4.6 and in the 
normal group 25.4 with a standard deviation of 4.6. The slow expressive and normal language development group were $70 \%$ male. The mean socioeconomic level, distributed evenly, was middle to lower-middle class according to the Hollingshead Scale (Meyers \& Bean, 1968), a 4-factor scale ranging from 1 to 5 with 1 being the highest. Fifteen percent of subjects in the normal language development group were nonwhite and $9 \%$ in the group with slow expressive language development were nonwhite. There were no birth order differences among the groups. Each subject passed a hearing screening at $25 \mathrm{~dB} \mathrm{HL}$, scored a developmental quotient of 85 or above on the Bayley Scale of Infant Mental Development (Bayley, 1969), and was without neurological deficit or autism. All subjects received in depth assessment of language skills and adaptive behavior at intake (Paul, 1991).

\section{TABLE 1}

DEMOGRAPHIC DATA FOR THE SUBJECTS AT INTAKE AND AGE 5: MEANS OR PERCENTAGE

\begin{tabular}{|c|c|c|c|c|c|c|}
\hline $\begin{array}{l}\text { Subject } \\
\text { Group }\end{array}$ & $N$ & $\begin{array}{l}\text { Age in } \\
\text { Months at } \\
\text { Intake } \\
(S D)\end{array}$ & $\begin{array}{l}\text { Age in } \\
\text { Months at } \\
\text { Age } 5 \\
(S D)\end{array}$ & Sex & SES & Race \\
\hline Normal & 27 & $\begin{array}{l}25.4 \\
(4.6)\end{array}$ & $\begin{array}{l}69.8 \\
(4.3)\end{array}$ & $\begin{array}{l}70 \% \text { Male } \\
30 \% \text { Female }\end{array}$ & 3.0 & $5 \%$ Nonwhite \\
\hline SELD & 33 & $\begin{array}{l}25.4 \\
(4.6)\end{array}$ & $\begin{array}{l}69.3 \\
(4.6)\end{array}$ & $\begin{array}{l}\text { 70\% Male } \\
30 \% \text { Female }\end{array}$ & 3.5 & $9 \%$ Nonwhite \\
\hline
\end{tabular}

Note. From "Profiles of Toddlers with Slow Expressive Language Development," by R. Paul, 1991, Topics in Language Disorders, 1, pp. 1-13. 


\section{PROCEDURES}

Children in the PLDP were followed yearly until age 7. At the evaluation at age 5, a questionnaire on child temperament was filled out by the parents of the children in the slow expressive language and normal language developing groups (see Appendix C). The parents were instructed to read each statement and judge the behavior of their child as occurring hardly ever (1) to almost always (7) in the situations. For each statement, the parent circled the number from 1 to 7 that best described their child's behavior. The parents were told that some questions may appear similar because they described the same situation. Each item assessed a specific behavior and was scored differently. Items that did not apply to the child were scored "NA" (not applicable).

\section{INSTRUMENT}

The temperament of the subjects was assessed using a questionnaire completed by the parents. The Parent Temperament Questionnaire for Children (Thomas et al., 1977) was utilized to asses temperament in this study. The questionnaire required the parents to read a sentence, such as "When first meeting new children, my child is bashful," "My child asks for or takes a snack at approximately the same time every day," and/or "My child sits still to have a story told or read, or a song sung." The parent assigned a number designating whether the behavior occurred in their child. The questionnaire included 72 items rated on a 7-point interval scale (i.e., $1=$ hardly ever, never, 2 = infrequently, $3=$ once in a while, $4=$ sometimes, $5=$ often, $6=$ very 
often, 7 = almost always, always). The 72 randomly ordered items include the dimensions of temperament, divided into 9 behavior categories. The categories include activity level, rhythmicity, approach-withdrawal, adaptability, threshold of responsiveness, intensity of reaction, quality of mood, distractibility, and attention span and persistence. The categories were defined as follows (Thomas \& Chess, 1977):

1. Activity Level - motor activity during daily routines and during sleep-wake cycles (high, medium, low).

2. Rhythmicity - regularity of vegetative functions (regular, variable, irregular).

3. Adaptability - ease of transition to altered or new situations (adaptive, variable, non-adaptive).

4. Approach-withdrawal - initial positive or negative response to a new stimulus (approach, variable, withdrawal).

5. Threshold of responsiveness - level of sensory stimulus required to evoke a response (high, medium, low).

6. Intensity of reaction - degree of a response (positive, variable, negative).

7. Quality of mood - the degree of positive or negative affect (positive, variable, negative). 
8. Distractibility - effectiveness of stimuli to alter on going behavior (distractible, variable, non-distractible).

9. Attention span and persistence - degree to which interest is maintained or activity is pursued in view of obstacles (persistent, variable, non-persistent).

Each temperament category contains eight questions; four questions in each of the upper and lower extremes of the behavior range (e.g., high and low activity, adaptive and non-adaptive). The behavioral range and the rated frequency of occurrence (e.g., 1 = hardly ever, never, 7 = almost always, always) of the behavioral item yield a weighted score. A weighted score is obtained by identifying the temperament category and locating the range. An upper extreme question (high activity) rated 7 is given a weighted score of 7 . A lower extreme question (low activity) rated 7 is given a weighted score of 1 . The total sum of all weighted scores in a category (e.g., activity) is divided by the total number of questions answered or eight if each question in the category is answered. The weighted score range for each temperament category is 1 to 7 and is reflective of the frequency of the high or low extremes of the behavioral items. A weighted score of 7 in the activity category would show an almost always or always occurrence of high activity and a hardly ever or never occurrence of low activity.

The Parent Temperament Questionnaire for Children (Thomas et al., 1977) was developed by combining 132 items of behavior distributed evenly among the nine temperament categories. The questionnaire was given to 74 mothers with 3 to 5 -yearold children and 74 mothers with 5 to 7 -year-old children, matched by socioeconomic 
status and sex. The mean and standard deviations were calculated for each questionnaire item and for each of the nine categories of temperament, obtained from the mothers. The correlations for age were only significant in the categories of mood and distractibility (.26 and .25). There were no significant differences for sex. Each questionnaire item was examined by the authors and four judges, according to the following criteria:

1. Statistically significant level of correlation of mean score of item with mean category score of questionnaire.

2. Absence of marked skewing in distribution of mother's responses to the item.

3. Zero or only small percentage of mothers failed to respond to the item.

4. Agreement among the four judges as to which category to respond to the item.

5. The behavior described in the item should define the category unambiguously.

6. The event cited in the item should be one with a fairly frequent recurrence of a representative daily activity.

7. The item should apply generally and not relate to a special activity found only in a minority of the families.

8. Compounded items should be avoided (e.g., "When playing with other children my child is happy" - playing may be equated with happy and the item should be changed to, "When with other children my child is happy"). 
9. The terminology should be behavioral rather than attitudinal (e.g., "My child prefers" should be changed to "My child selects").

The analysis of the items resulted in a 72-item questionnaire with eight items for each of the nine temperamental categories.

\section{DATA ANALYSIS}

In order to find if differences exist in the dimensions of temperament between children with a history of slow expressive language development and children with normal language development, each child was assigned a score for each of the nine behavior categories based on the parent's rating. A mean and standard deviation for each behavior category for each group was determined. The question posed by this study was, "Is there a significant difference in the dimensions of temperament between children with a history of slow expressive language development and children with normal language development?" To determine if there are significant differences in the dimensions of temperament among the groups, two-tailed $t$-tests were conducted for each behavior category at the .05 level of significance. It was hypothesized the $t$-test scores for the dimensions of temperament would be different between the groups. 


\section{CHAPTER IV}

\section{RESULTS AND DISCUSSION}

\section{RESULTS}

The purpose of this study was to determine if differences exist in the dimensions of temperament between children with a history of slow expressive language development and their peers with normal language development at age 5 as reported by parents. The questionnaire the parents utilized was the Parent Temperament Questionnaire for Children (Thomas et al., 1977).

The question this study addressed was whether or not significant differences exist in the behavior dimensions of temperament for children with slow expressive language development and children with normal language development. To answer this question, the means and standard deviations were compared for each behavioral category assessed on the Parent Temperament Questionnaire for Children for each group utilizing two-tailed $t$-tests. Differences between the two groups were considered significant at the .05 level. The score differences among the two groups are reported in Table 2.

On the Parent Temperament Questionnaire for Children (Thomas et al., 1977), differences were found between the subjects with a history of slow expressive language development and the subjects with normal language development for both 
TABLE 2

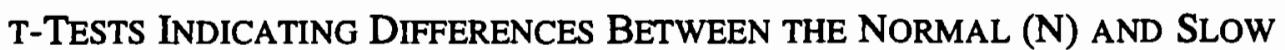
EXPRESSIVE LANGUAGE DEVELOPMENT (SELD) SUBJECTS ON THE PARENT TEMPERAMENT QUESTIONNAIRE FOR CHILDREN

\begin{tabular}{||l|c|c|c|c|c|c||}
\hline & \multicolumn{2}{|c|}{$\mathrm{N}$} & \multicolumn{2}{c|}{ SELD } & & \\
\hline Temperament Dimension & $M$ & $S D$ & $M$ & $S D$ & $t$ & $p^{<}$ \\
\hline Activity Level & 3.95 & .76 & 3.92 & .87 & .12 & .903 \\
\hline Rhythmicity & 4.83 & .77 & 5.13 & .84 & -1.41 & .164 \\
\hline Adaptability & 5.47 & .71 & 5.08 & .81 & 1.97 & .053 \\
\hline Approach-Withdrawal & 4.56 & .91 & 4.09 & .90 & 2.02 & $.048^{*}$ \\
\hline Threshold of Responsiveness & 3.46 & .72 & 3.12 & .71 & 1.86 & .068 \\
\hline Intensity of Reaction & 3.39 & .79 & 4.10 & .94 & -3.11 & $.003^{\star}$ \\
\hline Mod & 5.03 & .64 & 5.06 & .77 & -.14 & .890 \\
\hline Distractibility & 4.84 & .70 & 4.75 & .97 & .41 & .686 \\
\hline Attention Span/Persistence & 4.17 & .49 & 4.06 & .64 & .75 & .455 \\
\hline
\end{tabular}

$$
{ }^{*} p<.05 \text {. }
$$

approach-withdrawal and intensity of reaction. For the temperament dimension of approach-withdrawal, the subjects with slow expressive language development received a mean score of 4.56 and their peers with normal language development received a mean score of 4.09 . When analyzed, these results indicated that the subjects with slow expressive language development displayed more withdrawal behaviors than the children with normal language development. For example, the children with slow expressive language development were described by their parents as shy or bashful when meeting new people and unable to become comfortable when 
in a new surrounding or environment (e.g., on vacation, at a party). The children with normal language development were described by their parents as able to approach and join new children in play and infrequently upset when left in a novel situation (e.g., at school, during swimming lessons).

The subjects with slow expressive language development received a mean score of 4.10 and the subjects with normal language development received a mean score of 3.39 for intensity of reaction. The results show that children with a history of slow expressive language development display more intense reactions than the children with normal language development. The children with slow expressive language development were described by their parents as often crying or yelling when upset with an activity and infrequently accepting situations in stride, without becoming excited. The children with normal language development were described by their parents as infrequently upset when not getting candy or toys at the store and often will silently complain if another child takes his/her possession. The temperament dimensions of activity level, rhythmicity, adaptability, threshold of responsiveness, mood, distractibility, and attention span/persistence were not significantly different between the two groups (see Table 2).

\section{DISCUSSION}

The Parent Temperament Questionnaire for Children (Thomas et al., 1977) found that the subjects with a history of slow expressive language development display significantly different scores in the dimensions of approach-withdrawal and 
intensity of reaction than the subjects with normal language development. As shown in Table 3, the temperament dimension of approach-withdrawal and intensity of reaction included the following questions:

TABLE 3

\section{QUESTIONS FROM THE SIGNIFICANTLY DIFFERENT TEMPERAMENT DIMENSIONS ON THE PARENT TEMPERAMENT QUESTIONNAIRE FOR CHILDREN}

\begin{tabular}{|c|c|}
\hline $\begin{array}{c}\text { Temperament } \\
\text { Dimension }\end{array}$ & Question \\
\hline $\begin{array}{c}\text { Approach } \\
\text { Withdrawal }\end{array}$ & $\begin{array}{l}\text { 1. My child is shy with adults he/she does not know. } \\
\text { 2. When first meeting new people, my child is bashful. } \\
\text { 3. My child likes to try new foods. } \\
\text { 4. When in the park, at a party, or visiting, my child will go up to strange } \\
\text { children and join in their play. } \\
\text { 5. When the family takes a trip, my child immediately makes self at home } \\
\text { in the new surroundings. } \\
\text { 6. My child is immediately friendly with and approaches unknown adults } \\
\text { who visit our home. } \\
\text { 7. The first time my child is left in a new situation without mother (such } \\
\text { as school, nursery, music lesson, camp), he/she gets upset. } \\
\text { 8. My child would rather wear familiar clothes than new clothes. }\end{array}$ \\
\hline $\begin{array}{l}\text { Intensity of } \\
\text { Reaction }\end{array}$ & $\begin{array}{l}\text { 1. My child shows strong enthusiasm for food he/she likes or strong } \\
\text { dislike for food he/she does not like. } \\
\text { 2. When upset or annoyed with a task, my child may throw it down, cry, } \\
\text { yell, or slam door, etc. } \\
\text { 3. When taken away from an activity that my child really enjoys, he/she } \\
\text { protests only mildly, with a little bit of fussing or some whining. } \\
\text { 4. When scolded or reprimanded by parents, my child reacts mildly, such } \\
\text { as whining or complaining rather than strongly with crying or } \\
\text { screaming. } \\
\text { 5. When shopping together and mother does not buy candy, toys or } \\
\text { clothing that child wants, he/she cries and yells. } \\
\text { 6. When my child objects to wearing certain clothing, he/she argues } \\
\text { loudly, yells, cries. } \\
\text { 7. My child complains quietly when another child takes his/her toy away. } \\
\text { 8. My child seems to take things matter of factly. Accepts events in stride } \\
\text { without getting very excited. }\end{array}$ \\
\hline
\end{tabular}

Note. From Temperament and Development by A. Thomas and S. Chess, 1977, New York: Brunner Mazel, Inc., pp. 222-232. 
Other research seems to support these findings on the Parent Temperament Questionnaire for Children (Thomas et al., 1977), particularly in the area of withdrawal behaviors. The study conducted by Baker et al. (1980) also found that older language delayed children with a mean age of 5 years 8 months displayed significantly more problems with withdrawal behaviors. Parents in the study reported shyness, solitary behavior, and fear of new people as problems for the children with language disorders. The problems reported by teachers were similar to the parents, including submissiveness, lack of leadership ability, and difficulty with group participation. Further, Skarpness and Carson (1986) found communicative competence, children's ability to use verbal and nonverbal language correctly and effectively, to be "negatively related to children's withdrawal tendencies" (p. 1302). Another dimension of temperament which differed between the two groups was intensity of reaction. The Parent Temperament Questionnaire for Children (Thomas et al., 1977) showed the children with slow expressive language development to have significantly greater intensity of reaction than the normal language subjects. These findings are supported by the research of Chess (1974) who examined the behaviors of 139,4 to 5 -year-old children with language difficulties (e.g., delayed onset of development, speech usage below age, peculiar usage of language). The parents reported that $99(64 \%)$ of the children had behavioral difficulties. Chess (1974) found that a child with a language disorder experiences stresses.

The child's temperament will form an important element in determining how much stress the disorder produces. The patient, quietly persistent 
child will point, gesture, bring objects, and repeat sounds, all with little or no sense of frustration; the intensely reacting child may show easy frustration, exhibited through tantrum behavior. (Chess, 1974, p. 106).

The author suggests that a language disordered child with high intensity of reaction may develop secondary behavioral manifestations.

It is interesting to note that Paul and James (1990) investigated the behavior differences of the subjects with a history of slow expressive language development and their peers with normal language development at 2 years of age. Parents utilized the Childhood Personality Scale (Cohen, 1975) to rate their child's behavior. The results revealed that the subjects with slow expressive language development were perceived by their parents as having difficulty in the areas of activity and attention, conduct, and mood when compared to the parents' perceptions of the subjects with normal language development. Parents perceived the children with slow expressive language development as more active, inattentive, and difficult to manage than the children with normal language development.

This study suggests that the parents' perceptions of the behavior dimensions of temperament for the subjects with a history of slow expressive language development changed between 2 and 5 years of age. At 5 years of age, the child has acquired a tremendous amount of information about the world and communication skills in order to express himself. It may be that the 5-year-old children with slow expressive language development became withdrawn and shy as a result of the inability to express their desires, experiences, ideas, and feelings in order to be understood. Also, the children displayed more intense reactions possibly due to frustration, resulting 
from the language delay. Terestman (1980) supports the findings of this study. He examined temperament characteristics of 58 children between the ages of 3 and 5 years, and found that $87 \%$ of the children with high intensity of reaction were included in the clinical group, exhibiting disordered behavior. The ways in which the dimension of temperament were manifested by the subjects with slow expressive language development may have influenced the change in parental perceptions.

Thomas and Chess (1977) suggest that pure temperamental expression may appear during later development when coping skills are ineffective in dealing with novel environmental experiences. This finding is supported by Goldsmith et al. (1987), indicating that the dimensions of temperament show continuity and that it is the expression of temperament that is modifiable by the individual's environment. The children in this study attending kindergarten would have been exposed to classroom discourse rules and their peers with normal language development. Children are expected to follow classroom rules (e.g., independently completing activities, silent reading). They must adhere to the classroom schedule and negative or deviant behavior is no longer tolerated or acceptable.

Individual differences between children becomes apparent as the child enters the classroom environment. The child with a language disorder may be rejected or teased by peers with normal language development. This in turn could affect the self-esteem and self-image of a child with slow expressive language development. As a result, the child may withdraw to avoid negative attention. However, the child is no longer expressing emotions, such as sadness, anger, and/or frustration. This may result 
in the high intensity of reaction found in this study for the children with a history of slow expressive language development as reported by their parents. Beitchman, Hood, Rochon and Peterson (1989) found that more severely language delayed children tended to have difficulty functioning in social situations compared to their peers with normal language development. This novel environment may have influenced the temperamental differences between the two groups of children. Thus, differences in approach-withdrawal and intensity of reaction between the children with language disorders and their peers with normal language development may have been modified through environmental factors. 


\section{CHAPTER V}

\section{SUMMARY AND IMPLICATIONS}

\section{SUMMARY}

Children depend on language to express their emotions, ideas, intentions, and needs. Language is the means by which children form relationships with their parents, sibling, peers, and teachers. Language is the predominant mode of communication and primary method of socialization. It seems likely that if children's language skills are delayed, it will affect their social and emotional development. Research suggests that a relationship between language delays and behavior disorders exists (Cantwell \& Baker, 1977; Caulfield et al., 1989; Camarata et al., 1992). Numerous studies have focused on the behaviors of children with language disorders. The literature suggests that certain temperamental characteristics are linked to the development of behavior disorders among children (Bates, 1990; Fagot \& O'Brien, 1994; Graham et al., 1973). Terestman (1980) studied temperamental characteristics of 3 to 5-year-old children. It was found that $93 \%$ of the clinical group displayed negative mood and $87 \%$ exhibited high intensity of reaction. However, researchers have not investigated the temperamental characteristics of children with language delays or disorders. Therefore, this study was conducted to examine the temperamental characteristics of 
children with slow expressive language development and normal language development.

The purpose of this study was to determine if temperament differences exist between children considered to have a history of slow expressive language development and their peers with normal language development.

The question addressed by this study was: "Do children with a history of slow expressive language development and their peers with normal language development have different temperamental characteristics as measured on the Parent Temperament Questionnaire for Children?" (Thomas et al., 1977).

The means and standard deviations were computed for the nine dimensions of temperament for each group on the Parent Temperament Questionnaire for Children (Thomas et al., 1977). Differences were determined by comparing the $t$-test score results between the two groups of subjects, significant at the .05 level.

The results of this study indicate that children with slow expressive language development possess different temperamental characteristics than children with normal language development. The children with a history of slow expressive language development received significantly different scores than the children with normal language development in the dimensions of approach-withdrawal and intensity of reaction as reported on the Parent Temperament Questionnaire for Children (Thomas et al., 1977). 


\section{RESEARCH IMPLICATIONS}

Although several interesting findings emerged from this study, the need for further research exists. It provides some evidence that children with a history of slow expressive language development at 5 years of age have different temperamental characteristics than their peers with normal language development. Yet, no other research currently exists which examines the temperamental characteristics of children with language delays or disorders. In order to support the findings of this study, further research investigating the temperamental characteristics of children with language delays must be conducted. Also, it would be beneficial to determine whether or not the children continue to demonstrate a language delay. These findings would further substantiate the hypothesis that temperamental characteristics change as a result of the language delay or environmental factors.

Further research should be conducted to examine methods of language intervention (e.g., indirect, direct, collaborative) and the influence on temperamental characteristics of children with language delays or disorders. A study designed to determine if certain types of language intervention prevent the development of shyness and high intensity of reaction in children with slow expressive language development should be completed. In addition, researchers should investigate the effects of social experiences (e.g., play groups, kindergarten) on temperamental characteristics in children with language delays.

A limitation of this study was that the Parent Temperament Questionnaire for Children has not been evaluated for reliability or validity. The Parent Temperament 
Questionnaire for Children (Thomas et al., 1977) should be standardized to provide reliable and valid measures of temperament. The results of this study would have been strengthened if that information were available. A standardized sociogram may be a more reliable and valid tool to use when investigating the relationship between temperament and language disorders.

To date, additional studies examining the relationship between temperament and language disorders have not been completed. If researchers are able to further validate the results found in this study, those studies could substantiate the clinical implications.

\section{CLINICAL MMLICATIONS}

Results of this study show that children with a history of slow expressive language development have different temperamental characteristics than children with normal language development. As a result, this study has several clinical implications for the speech-language pathologist. It provides support for the trend toward the assessment of temperamental characteristics for children with language delays. It suggests that the implementation of counseling or training programs for parents and clinicians to react optimally to temperamental characteristics of a child with slow expressive language development may facilitate treatment and progress. In addition, it indicates the need for collaboration with all the professionals and family members involved with the child's care. In looking at the study by Paul and James (1990), it appears that behavior differences appear for these children even at a young age when 
compared to their peers with normal language development. It can be hypothesized that temperamental differences between the two groups do not disappear, but change possibly due to the language delay or environmental factors.

A speech-language pathologist will often counsel parents in techniques to facilitate language development for their child (e.g., indirect language stimulation techniques, decreasing the syntactic complexity of their utterances, reading to the child). This study suggests that the speech-language pathologist should also be responsible for providing parents with techniques to react optimally to the child's temperamental characteristics.

This study and the research by Paul and James (1990) shows a definite trend for children with language delays to display different behavior characteristics than children with normal language development. These studies found that behavior differences did not disappear, but changed in the older child with a history of slow expressive language development.

The speech-language pathologist should counsel parents that, initially, a young child with slow expressive language development may be active, inattentive, and difficult to manage. However, the older child with a history of slow expressive language development may become withdrawn or shy. Parents should maintain social opportunities for the child to interact with peers (e.g., play groups, kindergarten). Also, the older child with a history of slow expressive language development may display high intensity of reaction. The child should receive additional support in order to learn to describe and talk about emotions. Providing parents with counseling or 
training programs to effectively deal with temperamental characteristics of the child may in turn facilitate language development.

It is imperative that the speech-language pathologist share the knowledge that children with slow expressive language development may display different temperamental characteristics than their peers with normal language development. This study suggests the need of a multidisciplinary team approach to early intervention. The speech-language pathologist should be knowledgeable of temperament differences in language delayed children and be able to effectively interact with those temperamental characteristics. With no available research, it is difficult at this time to determine whether language delays lead to or are enhanced by differences in temperamental characteristics. The best approach appears to be one in which the speech-language pathologist and multidisciplinary team members (e.g., the classroom teacher, school psychologist, administrators, and parents) collaborate in order to develop the best possible treatment approach for these children. 


\section{REFERENCES}

American Psychiatric Association, Task Force on Nomenclature and Statistics. (1980). Diagnostic and statistical manual of mental disorders (3rd ed.). Washington, DC: Author.

Baker, L., \& Cantwell, D. (1982). Developmental, social and behavioral characteristics of speech and language disordered children. Child Psychiatry and Human Development, 12, 195-206.

Baker, L., Cantwell, D., \& Mattison, R. (1980). Behavior problems in children with pure speech disorders and in children with combined speech and language disorders. Journal of Abnormal Child Psychology, 8, 245-256.

Bates, J. (1990). Conceptual and empirical linkages between temperament and behavior problems: A commentary on the Sanson, Prior, and Kyrios study. Merrill-Palmer Quarterly, 36, 193-199.

Bayley, N. (1969). Scales of infant mental developoment. New York: Psychological Corporation.

Beitchman, J., Hood, M., Rochon, J., \& Peterson, M. (1989). Empirical classification of speech/language impairment in children: II. Behavioral characteristics. Journal of the American Academy of Child and Adolescent Psychiatry, $28,118-123$.

Buss, A., \& Plomin, R. (1984). Temperament: Early developing personality traits. Hillsdale, NJ: Erlbaum Associates.

Camarata, S., Hughes, C., \& Ruhl, K. (1992). Analysis of the expressive and receptive language characteristics of emotionally handicapped students served in public school settings. Journal of Childhood Communication Disorders, 14, 165-175.

Cantwell, D., \& Baker, L. (1977). Psychiatric disorders in children with speech and language retardation. Archives of General Psychiatry, 34, 583-591.

Caulfield, M., DeBaryshe, B., Fischel, J., \& Whitehurst, G. (1989). Behavioral correlates of developmental expressive language disorder. Journal of Abnormal Child Psychology, 17, 187-201. 
Chess, S. (1974). Clinical differentiation among children with initial language complaints. Journal of Autism and Childhood Schizophrenia, 4, 99-109.

Cohen, D. (1975). The childhood personality scale. Washington, DC: The National Institute of Mental Health.

Fagot, B., \& O'Brien, M. (1994). Activity level in young children: Cross-age stability, situational influences, correlates with temperament, and the perception of problem behaviors. Merrill-Palmer Quarterly, 40, 378-398.

Giddan, J., Jurs, S., \& Trautman, R. (1990). Language risk factor in emotionally disturbed children with a school and day treatment program. Journal of Childhood Communication Disorders, 13, 123-133.

Goldsmith, H., Buss, A., Plomin, R., Rothbart, M., Thomas, A., Chess, S., Hinde, R., \& McCall, R. (1987). Roundtable: What is temperament? Four approaches. Child Development, 58, 505-529.

Graham, P., Rutter, M., \& George, S. (1973). Temperamental characteristics as predictors of behavior disorders in children. American Journal of Orthopsychiatry, 43, 328-339.

Jewsuwan, R., Luster, T., \& Kostelnik, M. (1993). The relation between parents' perceptions of temperament and children's adjustment to preschool. Early Childhood Research Quarterly, 8, 33-51.

Kohnstamm, G., Bates, J., \& Rothbart, M. (Eds.). (1989). Temperament in childhood. New York: John Wiley \& Sons.

Lewis, M. (1977). Language, cognitive development, and personality. Journal of American Academy of Child Psychology, 16, 647-661.

Mehregany, D. (1991). The relation of temperament and behavior disorders in a preschool clinical sample. Child Psychiatry and Human Development, 22, 129-136.

Meyers, J., \& Bean, L. (1968). A decade later: A follow-up of social class and mental illness. New York: Wiley and Sons.

Mobley, C., \& Pullis, M. (1991). Temperament and behavioral adjustment in preschool children. Early Childhood Research Quarterly, 6, 577-586. York: Norton.

Orton, S. (1937). Reading, writing and speech problems in children. New 
Paul, R. (1991). Profiles of toddlers with slow expressive language development. Topics in Language Disorders, 1, 1-13.

Paul, R., \& James, D. (1990). Language delay and parental perceptions. Journal of the American Academy of Child and Adolescent Psychiatry, 29, 669-670.

Rescorla, L. (1989). The language development survey: A screening tool for delayed language in toddlers. Journal of Speech and Hearing Disorders, 54, 587-599.

Richman, N., \& Stevenson, J. (1978). Behavior, language, and development in three-year-old children. Journal of Autism and Childhood Schizophrenia, 8, 299-313.

Rothbart, M. (1981). Measurement of temperament in infancy. Child Development, 52, 569-578.

Scholom, A., Zucker, R., \& Stollak, G. (1979). Relating early child adjustment to infant and parent temperament. Journal of Abnormal Child Psychology, 7, 297-308.

Skarpness, L., \& Carson, D. (1986). Temperament, communicative competence and the psychological adjustment of kindergarten children. Psychological Reports, 59, 1299-1306.

Terestman, N. (1980). Mood quality and intensity in nursery school children as predictors of behavior disorder. American Journal of Orthopsychiatry, 50, 125-138.

Thomas, A., \& Chess, S. (1977). Temperament and development. New York: Brunner Mazel, Inc.

Thomas, A., Chess, S., \& Birch, H. (1968). Temperament and behavior disorders in children. New York: New York University Press.

Thomas, A., Chess, S., Birch, H., Hertzig, M., \& Korn, S. (1963). Behavioral individuality in early childhood. New York: New York University Press. 
APPENDIX A

HUMAN SUBJECT APPROVAL 
OFFICE OF GRADUATE STUDIES AND RESEARCH

Research and Sponsored Projects

DATE: $\quad$ May 7th 1995

TO: $\quad$ Beth Jones $\quad$ SSN\# 318-66-7471

FROM: for Laurie Skokan, Chair, HSRRC, 1994-95 Raygn Movalid

RE: $\quad$ HSRRC Waived Review of Your Application titled "Temperament Differences in Children with Language Delays"

Your proposal is exempt from further HSRRC review, and you may proceed with the study.

Even with the exemption above, it was necessary by University policy for you to notify this Committee of the Proposed research and we appreciate your timely attention to this matter. If you make changes in your research protocol, the Committee must be notified. This approval is valid for one year from date of issue.

c: $\quad$ Maureen Orr Eldred

Rhea Paul, Project Advisor

waiver.mem 
APPENDIX B

DEMOGRAPHIC DATA FOR SUBJECTS 
DEMOGRAPHIC DATA AT INTAKE AND AGE 5

NORMAL (N)

\begin{tabular}{||r|c|c|c|c|c|c||}
\hline & N & \multicolumn{2}{|c|}{ A } & S & SES & R \\
\hline 4 & 1 & 23 & 70 & 1 & 3 & 3 \\
9 & 2 & 19 & 68 & 1 & 3 & 3 \\
14 & 3 & 25 & 61 & 1 & 4 & 1 \\
27 & 4 & 22 & 68 & 1 & 3 & 1 \\
32 & 5 & 29 & 63 & 1 & 3 & 2 \\
36 & 6 & 28 & 74 & 2 & 4 & 1 \\
40 & 7 & 25 & 76 & 2 & 3 & 1 \\
50 & 8 & 24 & 71 & 1 & 4 & 1 \\
51 & 9 & 20 & 68 & 2 & 3 & 1 \\
58 & 10 & 34 & 77 & 1 & 1 & 1 \\
59 & 11 & 34 & 77 & 2 & 1 & 1 \\
63 & 12 & 19 & 69 & 1 & 3 & 1 \\
72 & 13 & 20 & 68 & 1 & 3 & 1 \\
78 & 14 & 26 & 71 & 1 & 2 & 1 \\
81 & 15 & 26 & 72 & 2 & 2 & 1 \\
95 & 16 & 19 & 67 & 1 & 3 & 1 \\
113 & 17 & 26 & 70 & 2 & 4 & 1 \\
129 & 18 & 33 & 75 & 1 & 2 & 1 \\
130 & 19 & 29 & 70 & 1 & 4 & 1 \\
131 & 20 & 31 & 71 & 1 & 4 & 1 \\
132 & 21 & 20 & 68 & 1 & 4 & 3 \\
133 & 22 & 27 & 71 & 1 & 3 & 1 \\
138 & 23 & 23 & 69 & 1 & 4 & 1 \\
139 & 24 & 29 & 71 & 2 & 3 & 1 \\
141 & 25 & 22 & 66 & 1 & 4 & 1 \\
144 & 26 & 24 & 68 & 1 & 2 & 1 \\
150 & 27 & 28 & 66 & 2 & 4 & 1 \\
\hline
\end{tabular}

$\mathrm{KEY}: \mathrm{N}=$ Number $\bullet \mathrm{A}=$ Age in months $\bullet \mathrm{S}=\mathrm{Sex} \cdot \mathrm{SES}=$ Socioeconomic status $\bullet \mathrm{R}=$ Race 
DEMOGRAPHIC DATA AT INTAKE AND AGE 5

SLOW EXPRESSIVE LANGUAGE DEVELOPMENT (SELD)

\begin{tabular}{||c|c|c|c|c|c|c||}
\hline & N & \multicolumn{2}{|c|}{ A } & S & SES & R \\
\hline 6 & 1 & 23 & 70 & 1 & 4 & 1 \\
7 & 2 & 23 & 70 & 1 & 4 & 1 \\
12 & 3 & 22 & 69 & 2 & 4 & 1 \\
15 & 4 & 32 & 71 & 1 & 3 & 1 \\
19 & 5 & 32 & 69 & 2 & 3 & 1 \\
26 & 6 & 31 & 70 & 1 & 3 & 2 \\
29 & 7 & 26 & 72 & 2 & 4 & 1 \\
39 & 8 & 22 & 70 & 1 & 4 & 1 \\
41 & 9 & 21 & 70 & 1 & 3 & \\
55 & 10 & 26 & 72 & 2 & 3 & 1 \\
57 & 11 & 20 & 70 & 2 & 2 & 1 \\
60 & 12 & 29 & 62 & 1 & 4 & 1 \\
84 & 13 & 20 & 68 & 1 & 4 & 1 \\
85 & 14 & 28 & 70 & 1 & 3 & 1 \\
86 & 15 & 20 & 68 & 1 & 4 & 1 \\
87 & 16 & 25 & 70 & 2 & 3 & 1 \\
92 & 17 & 33 & 69 & 1 & 4 & 1 \\
93 & 18 & 23 & 69 & 1 & 3 & 1 \\
94 & 19 & 31 & 72 & 1 & 4 & 1 \\
97 & 20 & 32 & 69 & 1 & 3 & 1 \\
98 & 21 & 19 & 66 & 1 & 4 & 1 \\
100 & 22 & 29 & 71 & 1 & 4 & 1 \\
103 & 23 & 24 & 69 & 1 & 4 & 1 \\
105 & 24 & 25 & 68 & 1 & 2 & 1 \\
107 & 25 & 21 & 67 & 1 & 4 & 1 \\
109 & 26 & 20 & 67 & 1 & 3 & 1 \\
111 & 27 & 25 & 70 & 2 & 3 & 1 \\
114 & 28 & 24 & 68 & 1 & 4 & 3 \\
116 & 29 & 32 & 74 & 1 & 2 & 1 \\
119 & 30 & 26 & 68 & 1 & 4 & 1 \\
122 & 31 & 25 & 70 & 2 & 4 & 2 \\
142 & 32 & 22 & 67 & 2 & 4 & 1 \\
153 & 33 & 27 & 73 & 1 & 3 & 1 \\
\hline & & & & & & \\
\hline
\end{tabular}




\section{APPENDIX C}

PARENT TEMPERAMENT QUESTIONNAIRE FOR CHILDREN 


\section{PARENT TEMIPERAIIENT QUESTIONNAIRE FOR CHILDREN. \\ (Irom the NYLS of Thouns, Chess and Korn)}

This questionnaire is desigued to gather information on the pray your child behaves In different sttuatlons if everyday life. Each statement asks you to Judge whether that behavior securs hardly ever, injrequently, once in a while, sometimes, often, very oflen or almost always. Before each statement, please drcle the number from $I$ to 7 that best describes your child's behavior. The statements oftes. involve making judgments (such as whether your child does something "quickly" or "slowly," for a "long time" and so on). Please try to make these judgments to the best of your ability, based on how you think your child compares to other children of about the same age.

Some statements may seem slmilar to each other because they ask about the same situation. However, each one looks at a different area of the child's behavior: Therefore, your answers may be different in each case.

A fer llems may not apply to your child (such as questions about school for those children not yet in school). In tiat case, please write "NA" (not applicable) pext to the ftem.

$\begin{array}{ccccccc}1 & 2 & 3 & 4 & 5 & 6 & 7 \\ \begin{array}{c}\text { hardly } \\ \text { ever, } \\ \text { never }\end{array} & & \text { infrequently } & \begin{array}{c}5 \\ \text { once in } \\ \text { while }\end{array} & \text { sometimes often } & \begin{array}{c}\text { very } \\ \text { olmost } \\ \text { almays, } \\ \text { almays }\end{array}\end{array}$

1. My child splashes bard In the bath and plays actively.

1. When with other children, my children seems to be having a good time.

3. My child quickly notices odors and commenes on unpleasant smells.

4. My child is shy with adults he/sbe does not know.

5. When my child starts a project such as model, puzzle, painting, be/she works at It without stopping until completed, even if it lakes a long time.

6. My child bas a bowel movement at about the same time every day.

7. My child non ents lood that she/he used to dislike.

8. My child shows strong enthusiasm for lood be/she like or strong dislike for lood he/sbe does not like.
9. If my child is in a bad mood, he/sbe can easily be "joked" out of it.

10. When bist meeting new children, my child ls bashIul.

11. My child ignores loud noises. For example, be/ she is the last to complaio about music being too loud, sirens, etc.

12. If my child is not permitted to mear an Item of clotbing be/she selects, be/ she accepts rearing mother's choice after a short discussion.

13. My child asks for or takes a snact at approximately the sar.e time every day.

14. My child is bappy and pleased when telling about something that bas bappened during the day.

15. My child is at ease withln a lew visits when visiting at someone els:'s home.
16. When upset or ennoyed with a last my child may tbrow It down, cry, yell or slam door, etc.

17. If my child wants a toy or candy (whlle stopping) be/she will easily accept something else offered instead.

18. When my child moves about in the house or outdoors, be/sbe runs rather than ralks.

19. My child enjoys golng shopping with parents.

20. Alter my child is put to bed at aight It takes about the same length of time to fall asleep.

21. My child likes to try new loods.

22. When mother is busy and cannot do what chlld wants, he/she goes away and does something else instead of keeping ifter mother. 
23. My child quickly iotices colors (lor example, may comment on how pretty or ugly they are).

24. In the playground, my child runs, climbs, snings and is constantly on the zo.

25. If my child resists some procedure, such as having hair cut, brushed or washed, be/sbe will conunue to resist lt for at least several months.

26. If there is a sudden noise or sculvity nearby when my child is playing with a favorite toy, be/she ignores It, or at most, looks up briebly.

27. When taten array from an activity that my child really enjoys, be/she protests oaly mildly, with a little bit ol fussing or some whining.

28. When my child is promised something in the future, be/she keeps reminding parents constantly.

29. When playing with other children, my child argues with them.

30. When in the park, at a party or visiting, my chlld will go up to strange children and join in thelr play.

31. My child sleeps more one night and less another night, rather than the same number of bours each ajght.

32. My child ignores the temperature of loods (hot or cold).
33. If my child is shy with a strange sdull be/sbe qulckly (within a ball-bour or so) gets over thls.

34. My child sits stlll to bave a story told or read, or a song sung.

35. When scolded or tepri. manded by parents, my child reacts mildly, such as whinjog or complaining rather than strongly with crying or screaming.

36. When my clild becomes angry about something, it is difsault to sidetrack him/her.

37. When learning a ner physical activity (such as bopping, skatug ; bike riding) my child will spend long periods of time practicing.

38. My chili gets bungry at different umes each day.

39. My child is highly sensilive to changes in the brightness or dimness of light.

40. When atray from bome with parents, my child has - problem (':ven alter a (er nights) in falling asleep in a ner bed.

41. My child looks formard to going to shbool.

12. When the Iamily lakes a trip, my child Immediately makes self at home in the gew surroundings.

13. When slopping logether and mother does not buy candy, toys or clothing that child wants, be/she cries and yells.

44. If my child is upset, it is hard to a mfort him/her.
45. When the neather is bad and my child is confined to the bouse, be/she runs around and cannot be entertalned by quiet activltles.

16. My child is immediately Itiendly with and approsches untoorra adults who visit our home.

17. My child eats a lot ove day and very little the next day, rather than the same amount each day.

18. When a toy or game is diffcult, my child will turn quickly to anolber activity.

19. My child ignores diliereaces in temperature, in. doors or outdoors.

50. If a favorito toy or game is broken, wy child gets noticeably upset.

51. In i new siluatlon, such as 2 oursery, day care center, or school my child is still uncomfortable even after a lew days.

52. N though my child disllkes some procedures (such is nall cutting or hair brush. Ing), be/she will casily allow it il watching televsion or being entertalned while it is done.

53. My child can sit quielly through an entire childrea's movie, baseball game, or a long TV program.

54. When my child objects to wearing certain clothing, be/she argues loudly, yells, cries. 
55. On weekends and holidays my child wates himself/ berself up at the same time each morning.

56. My child complains to own parents about other children if anything goes wrong.

57. My child is sensitive and complains about clothing being tight, itchy or uncomfortable.

58. If my child is angry or annoyed, he/she gets over it quickly.

59. When there is a change in daily routine, such as not being able to go to school, change of usual daily activities, etc., my child goes along with the new routine easily.

60. When outdoors, in a playground or park, my child plays quietly with toys or dolls.

61. My child complains quietly when another child takes his/her toy array.

62. The first time my child is left in a new situation without mother (such 25 school, nursery, music lesson, camp), he/she gets upset.

63. If my child starts to play with something and I want him to stop, it is hard to turn his attention to something else.
64. My child gets involved in quiet activities such as crafts, watching television, reading or looking at picture books.

65. My child becomes easily upset when he/she loses a game.

66. My child would rather rear familiar clothes than new clothes.

67. If my child gets dirty or wet, he/she ignores this and appears quite comfort. sble.

68. My child has difficulty in adjusting to rules of another household, if they are different from those at bome.

69. My child seems to take things matter of factly. Accepts events in stride without getting very excited.

70. If meals are delayed for an bour or more, my child easily waits without seem. ing to mind.

71. My child can be stopped from pestering if be/she is given something else to do.

72. When assistance is offered in doing a task, my child continues to do it on bis/ ber own. 
Arismar Shogt-nYLS PARENT TEMPERAMENT QUESTIONNAIRE (Thombs, Choss \& Korn) ChIld's Neme Aç̣ Dato

Quest Ionnalre Complated By

PLEASE INOICATE YOUR RESPONSE GY PLACING AN " $X$ " aCROSS THE RESPONSE NLmber* FOR EACH QUESTION.

IF A QUESTION IS NOT APPLICABLE BECAUSE OF SPECIAL CONDITIONS. DRAW A LINE ACROSS THE QUESTION NUMBER ANO THE RESPUNSE ALTERNATIVES.

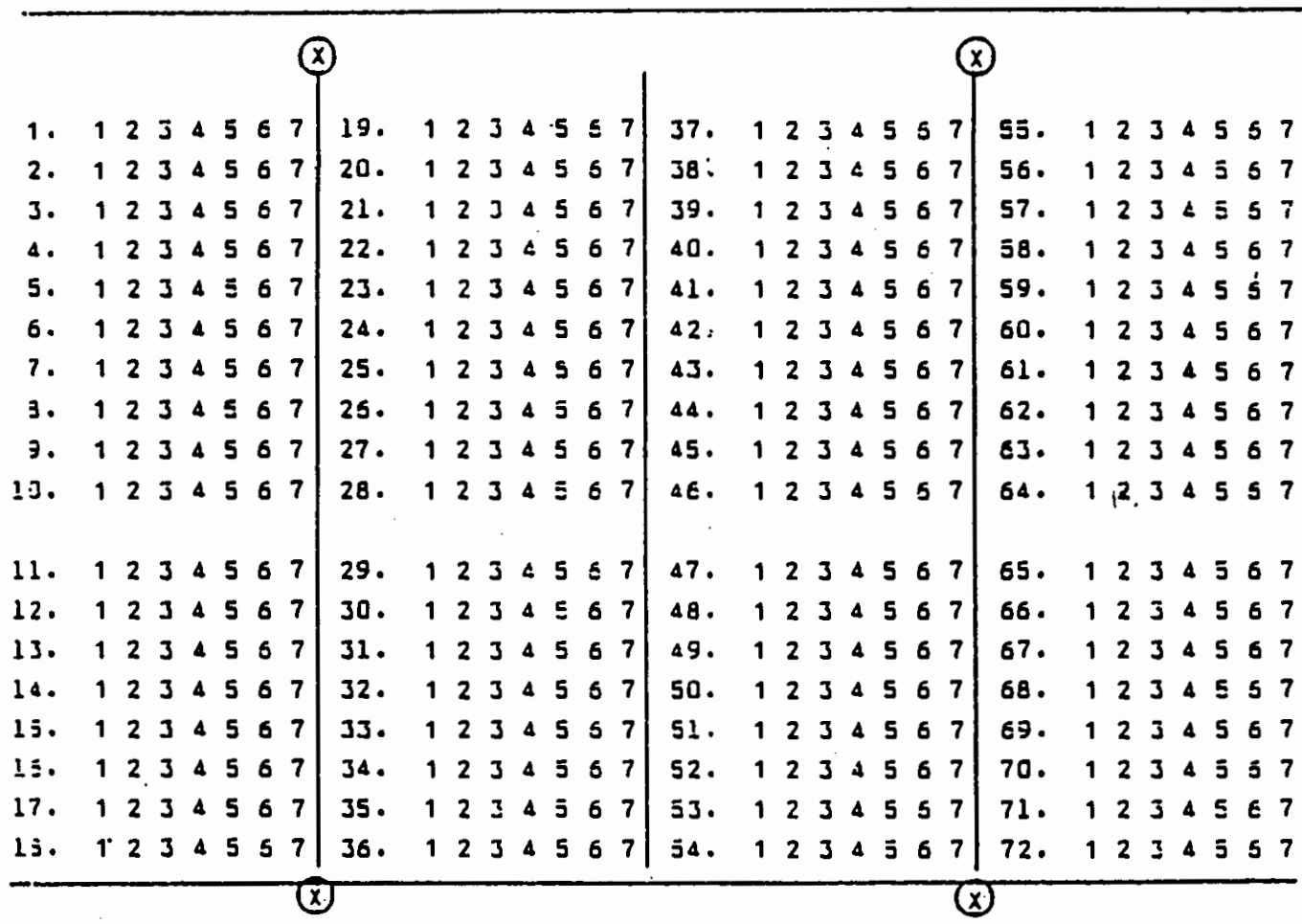

"agsoonse alterngt lves"

\begin{tabular}{|c|c|c|c|c|c|c|}
\hline 1 & 2 & 3 & 4 & $E$ & 5 & 7 \\
\hline $\begin{array}{l}\text { Hardly } \\
\text { ever or } \\
\text { never }\end{array}$ & $\begin{array}{l}\text { Infre- } \\
\text { quent } 1 \text { y }\end{array}$ & $\begin{array}{l}\text { Once in } \\
\text { a while }\end{array}$ & $\begin{array}{l}\text { Some- } \\
\text { times }\end{array}$ & often & $\begin{array}{l}\text { Very } \\
\text { often }\end{array}$ & $\begin{array}{l}\text { A lmast } \\
\text { a lways } \\
\text { always }\end{array}$ \\
\hline
\end{tabular}

\begin{tabular}{l|l|l|l|l|l|l|l|l|l|}
\hline & Act Iv & Rhyth & Adaot & Apo/w & Ihras & Inten & mood & OL str & Pers \\
\hline Total We Lghts & & & & & & & & & \\
\hline Itams - Nugber & & & & & & & & & \\
\hline Wolghted Scor & & & & & & & & & \\
\hline
\end{tabular}


Thomas, Chesy \& Karn

MOOD

- NYLS Parent Temperament Ouastlonnairat Scarling Kay

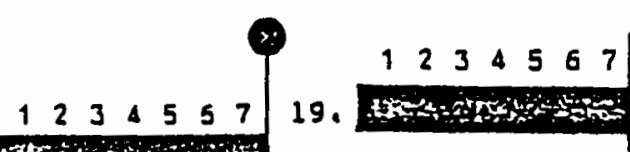

2. $10+4$

$\begin{array}{lllllll}7 & 6 & 5 & 4 & 3 & 2 & 1\end{array}$

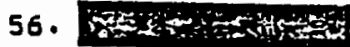

$\begin{array}{lllllll}1 & 2 & 3 & 4 & 5 & 5 & 7\end{array}$

41. 1+4

$\begin{array}{lllllll}7 & 6 & 5 & 4 & 3 & 2 & 1\end{array}$

$\begin{array}{lllllll}7 & 6 & 5 & 4 & 3 & 2 & 1\end{array}$

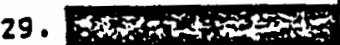

65. 168

1234567

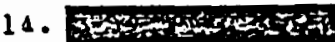

$\begin{array}{lllllll}7 & 6 & 5 & 4 & 3 & 2 & 1\end{array}$

50. i.

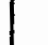


Thomas, Chess \& Korn

APPROACH/WITHDRAWAL - NYLS Parant 'Tgmparament QuEstlonnalre: Scorlng Key

7654329

10. $\begin{array}{lllllll}1 & 2 & 3 & 4 & 5 & 5 & 7\end{array}$

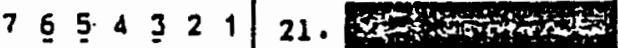

4.

1234567

30. Shy
1234567

42.

$\begin{array}{lllllll}7 & 6 & 5 & 4 & 3 & 2 & 1\end{array}$

62.

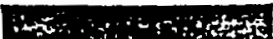

$123 i 567$

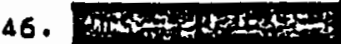

$\begin{array}{lllllll}7 & 6 & 4 & 3 & 2 & 1\end{array}$

66. 40.96

\section{TEMPLATE \& SCORTNG INSTRUCTIONS}

1. Carefully cut out the darkened areas on the template.

2. The round holes aro for contering the template over the $X$ s on response shest

3. The walght of ech response ls Indliated above the response alternatives to each question.

4. Sum the response welghts and record in the table below.

5. Record the number of questlon: answered by the informant.

6. Dlvide the sum of the rasoonse welghts by the number of questions ansmered.

7. Recard the result of the division (step 6) as the walghted score.

\begin{tabular}{|c|c|c|c|c|c|c|c|c|c|}
\hline S & Act IV & Ahyth & Adant & 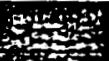 & Thres & Inten & mood & D1str & Pers \\
\hline 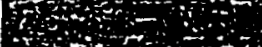 & & & & $1+4$ & & & & & \\
\hline 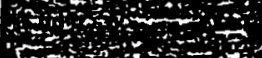 & & & & 4 & & & & & \\
\hline 65 & & & & $x \rightarrow 4$ & & & & & \\
\hline
\end{tabular}

Resoonse plernat Ivea'

\begin{tabular}{|c|c|c|c|c|c|c|}
\hline 1 & 2 & 3 & 4 & 5 & 6 & 7 \\
\hline $\begin{array}{l}\text { Hardly } \\
\text { ever or } \\
\text { never }\end{array}$ & $\begin{array}{l}\text { Infre- } \\
\text { quentiy }\end{array}$ & $\begin{array}{l}\text { Once In } \\
\text { a whtle }\end{array}$ & $\begin{array}{l}\text { Some- } \\
\text { tImes }\end{array}$ & ortan & $\begin{array}{l}\text { Very } \\
\text { opten }\end{array}$ & $\begin{array}{l}\text { Almost } \\
\text { almays } \\
\text { almays }\end{array}$ \\
\hline
\end{tabular}


Thomaa, Chesy \& Korn

THRESHOLD

- NYL5 Parent Temperament questionnalra, Scoring Key

$\begin{array}{lllllll}7 & 6 & 5 & 4 & 3 & 2 & 1\end{array}$

3.

$\begin{array}{lllllll}7 & 6 & 5 & 4 & 3 & 2 & 1\end{array}$

23.

1234567

11. F

$\begin{array}{lllllll}1 & 2 & 3 & 4 & 5 & 6 & 7\end{array}$

32. Ex+1

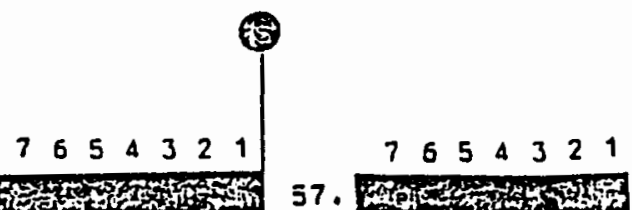

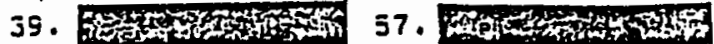

$12345 \leqslant 7$

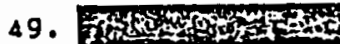

12234567

67.

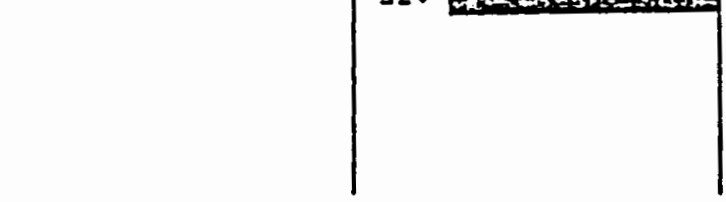

यु)

\section{IEMPLATE \& SCOAIHC INSTRUCTIONS}

1. Carsfully cut out the daskened areas on the template.

2. The round holes are for contering the template over the $(X)$ s on response sheet

3. The welght of each response is indicated above the response altarnatives to each question.

4. Sum the response welghts and record in the taola selow.

5. Racord the number of questions answered by the informant.

6. Divide the sum of the resjonse welghts by the number of questions enswered.

7. Record the result of the division (step 6) as the waighted Score.

\begin{tabular}{|c|c|c|c|c|c|c|c|c|c|}
\hline 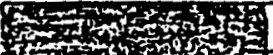 & Act 1v & Rhyth & Adapt & $A D D / W$ & Fints & Inten & Mood & Dest & Pars \\
\hline$-3=-30$ & & & & & 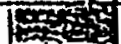 & & & & \\
\hline 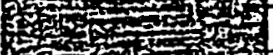 & & & & & Exing & & & & \\
\hline 证 & & & & & & & & & \\
\hline
\end{tabular}

Resognse itsornat ives:

\begin{tabular}{|c|c|c|c|c|c|c|}
\hline 1 & 2 & 3 & 4 & 5 & 6 & 7 \\
\hline $\begin{array}{l}\text { Hardly } \\
\text { over or } \\
\text { never }\end{array}$ & $\begin{array}{l}\text { Infre- } \\
\text { quently }\end{array}$ & $\begin{array}{l}\text { Once in } \\
\text { a while }\end{array}$ & $\begin{array}{l}\text { Some- } \\
\text { times }\end{array}$ & Orten & $\begin{array}{l}\text { Vary } \\
\text { oftan }\end{array}$ & $\begin{array}{l}\text { Almost } \\
\text { always } \\
\text { alweys }\end{array}$ \\
\hline
\end{tabular}


Thomas. Chess \& Karn

$\begin{array}{lllllll}1 & 2 & 3 & 4 & 5 & 6 & 7\end{array}$

7.

$123 \& 567$

15. $\begin{array}{lllllll}7 & 6 & 5 & 4 & 3 & 2 & 1\end{array}$

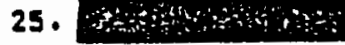

$\begin{array}{lllllll}7 & 6 & 5 & 4 & 3 & 2 & 1\end{array}$

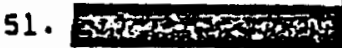

40.

59.
1234567 $\begin{array}{lllllll}7 & 6 & 5 & 4 & 3 & 2 & 1\end{array}$

68.

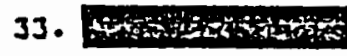

\section{TEMPLATE \& SCOAIHG INSTRUCTIONS}

1. Carefully cut out the darkensu araas oir the tamplate.

2 . The round holes are por contering the template over the $X$ s on response shert

3. The Weight of each response is indicated above the response altarnatives to each question.

4. Sum the response waights and recard in the tablo below.

5. Record tha number of quastions answered by the infarmant.

6. Divide the sum of the resoonsa welghts by the number of questlons answered.

7. Record the rasult of the division (steip 6) as the weightad 5cora.

\begin{tabular}{|c|c|c|c|c|c|c|c|c|c|}
\hline 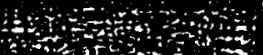 & Activ & Rhyth & $+3=i$ & Aoo/W & Thres & Inten & mood & Lo1st & $P_{\text {es }}$ \\
\hline & & & & & & & & & \\
\hline 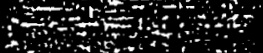 & & & $=$ & & & & & & \\
\hline 96 & & & & & & & & & \\
\hline
\end{tabular}

Resognse alternat fugs,

\begin{tabular}{|c|c|c|c|c|c|c|}
\hline 1 & 2 & 3 & 4 & 5 & 6 & 7 \\
\hline $\begin{array}{l}\text { Hardly } \\
\text { ever or } \\
\text { never }\end{array}$ & $\begin{array}{l}\text { Infre- } \\
\text { quent ly }\end{array}$ & $\begin{array}{l}\text { Ones in } \\
\text { a while }\end{array}$ & $\begin{array}{l}\text { Soma- } \\
\text { tlmes }\end{array}$ & orten & $\begin{array}{l}\text { VaEy } \\
\text { often }\end{array}$ & $\begin{array}{l}\text { A lmast } \\
\text { always } \\
\text { almays }\end{array}$ \\
\hline
\end{tabular}




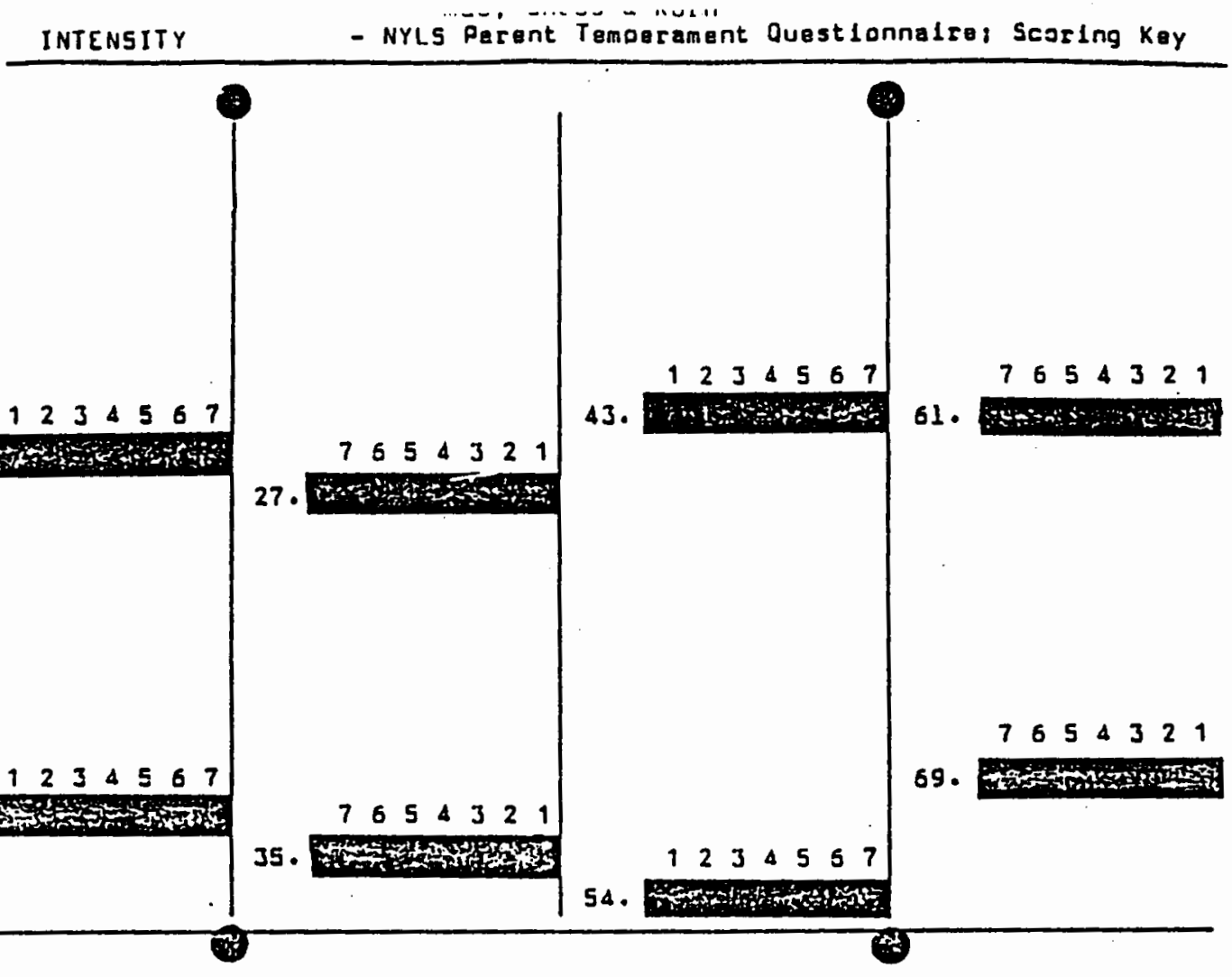

\section{TEMPLATE \& SCOAIHG INSTAUCTIONS}

1. Carafully cut out the darkaned areas on the template.

2 . The round holes are for contaring the template over the $X$ s an cosponse sheat

3. The lelght of each response is Indicatad above the response alternatives to each question.

4. Sum the response melghts and recard in the table below.

5. Record the number of questlons answered by the informant.

6. Divide the sum of the response walghtsiby the number of quastlons answered.

7. Record the result of the division (step 6) as the woighted Score.

\begin{tabular}{|c|c|c|c|c|c|c|c|c|c|}
\hline$m x^{5}=6$ & Act 14 & Fhyth & Adnot & Aoo/w & Thres & 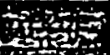 & mood & ongtr & Pars \\
\hline 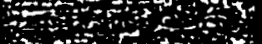 & & & & & & & & & \\
\hline 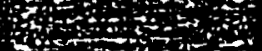 & & & & & & & & & \\
\hline$\therefore$ & & & & & & & & & \\
\hline
\end{tabular}

Resoonge lternatives:

\begin{tabular}{|c|c|c|c|c|c|c|}
\hline 1 & 2 & 3 & 4 & 5 & 6 & 7 \\
\hline $\begin{array}{l}\text { Hardly } \\
\text { over or } \\
\text { never }\end{array}$ & $\begin{array}{l}\text { Infre- } \\
\text { quent ly }\end{array}$ & $\begin{array}{l}\text { Onca in } \\
\text { a while }\end{array}$ & $\begin{array}{l}\text { Some- } \\
\text { times }\end{array}$ & Oftan & $\begin{array}{l}\text { Very } \\
\text { often }\end{array}$ & $\begin{array}{l}\text { Almost } \\
\text { eluays } \\
\text { always }\end{array}$ \\
\hline
\end{tabular}


Thomas, Chess \& Korn

\section{7}

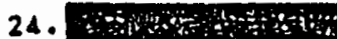

$\begin{array}{lllllll}7 & 6 & 5 & 4 & 3 & 2 & 1\end{array}$

34. Ffracis $\begin{array}{lllllll}7 & 6 & 5 & 4 & 3 & 2 & 1\end{array}$

60.

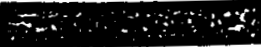

$\begin{array}{lllllll}1 & 2 & 4 & 5 & 67\end{array}$ 45. $19+40$

7654321

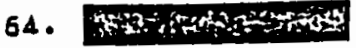

$\begin{array}{lllllll}7 & 6 & 5 & 4 & 3 & 2 & 1\end{array}$

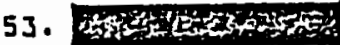

\section{TEMPLATE \& SCORIMG INSTAUCTIONS}

1. Carefully cut out the darkaned areas on the template.

2. The round holas are for centering the template over the $X$ s on response sheet

3. The Helght of each responsa is indicatrd above the iesponse altarnatives to each question.

4. Sum the response alghts and record in the table below.

5. Record the number of guestlons answered by the informant.

5. Dlvide the sum of the resoonse welghts by the number of questlons answered.

7. Record the result of the division $(s ; 0 p 5)$ as the walghted 5core.

\begin{tabular}{|c|c|c|c|c|c|c|c|c|}
\hline A & Ahyth & Adaot & $A 00 / 42$ & Thres & inten & mood & Olstr & Pors \\
\hline 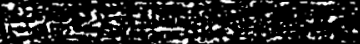 & & & & & & & & \\
\hline 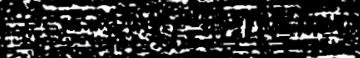 & & & & & & & & \\
\hline 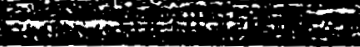 & & & & & & & & \\
\hline
\end{tabular}

Resoonge literngt lugs!

\begin{tabular}{|c|c|c|c|c|c|c|}
\hline 1 & 2 & 3 & 4 & 5 & 6 & 7 \\
\hline $\begin{array}{l}\text { Hardly } \\
\text { ever or } \\
\text { never }\end{array}$ & $\begin{array}{l}\text { Infre- } \\
\text { quentiy }\end{array}$ & $\begin{array}{l}\text { Once in } \\
\text { a while }\end{array}$ & $\begin{array}{l}\text { Some- } \\
t \text { Imes }\end{array}$ & often & $\begin{array}{l}\text { Ve:y } \\
\text { often }\end{array}$ & $\begin{array}{l}\text { Almost } \\
\text { always } \\
\text { l Imays }\end{array}$ \\
\hline
\end{tabular}


Inomas. Liness korn

(6)

1234567

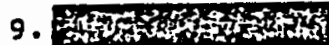

$\begin{array}{lllllll}1 & 2 & 3 & 4 & 5 & 6 & 7\end{array}$

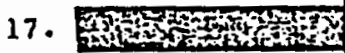

$\begin{array}{lllllll}7 & 6 & 5 & 4 & 3 & 2 & 1\end{array}$

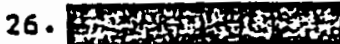

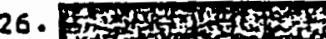

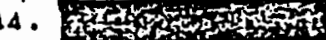

$\begin{array}{lllllll}7 & 6 & 5 & 4 & 3 & 2 & 1\end{array}$

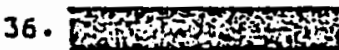

$12345 \div 7$

52. 2010
6

$\begin{array}{lllllll}7 & 6 & 5 & 4 & 3 & 2 & 1\end{array}$

63.

1234557

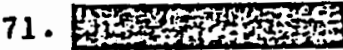

\section{IEMPLATE\& SCORIHE INSTRUCTIONS}

1. Careiully cut out tha darkened areas on the template.

2 . The round holas are for centaring the template over the $x$ s cn zesponse sheet

3. The leight of each response is indicated above the response alternatives to each question.

4. Sum the ressonse waights and record lo the table talow.

5. Aecord the numbez of questions answerad by the infosmant.

6. Divide the sum of the resoonse weights by the number of questions answered.

7. Fecord the rasult of the division (step 6) es the idelghted Scors.

\begin{tabular}{|l|l|l|l|l|l|l|l|l|}
\hline & Activ & Ahyth & Adaot & Aoo/w & Thres & Inten & mood \\
\hline & & & & & & & & \\
\hline
\end{tabular}

Fiesoonsa a! ternat lueg:

\begin{tabular}{|c|c|c|c|c|c|c|}
\hline 1 & 2 & 3 & 4 & $\overline{5}$ & 5 & 7 \\
\hline $\begin{array}{l}\text { Herdly } \\
\text { ever or } \\
\text { never }\end{array}$ & $\begin{array}{l}\text { Infre- } \\
\text { quantiy }\end{array}$ & $\begin{array}{l}\text { Once In } \\
\text { a whlle }\end{array}$ & $\begin{array}{l}\text { Some- } \\
\text { timas }\end{array}$ & arten & $\begin{array}{l}\text { vezy } \\
\text { aften }\end{array}$ & $\begin{array}{l}\text { Almost } \\
\text { a lways } \\
\text { always }\end{array}$ \\
\hline
\end{tabular}


Thomas, Chess \& Korn

RHYTHM ICITY - NYLS Parant Temperament Duestionnalral Scoring Key

1234567

6.

1234557

20. Mistions

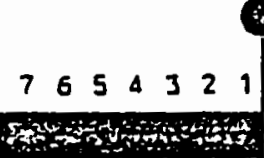

$123 \triangleleft 567$

20

55.

38. Fistising

7. 6554321

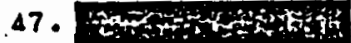

1234567

$\begin{array}{lllllll}7 & 6 & 5 & 4 & 3 & 2 & 1\end{array}$

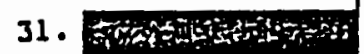

13.

7654321

70.

TEMPLATE \& SCORIUG IUSTRUCTIONS

1. Carefully cut out the darkened areas on the template.

2. The round holes are for centering the semplate over the $x$ s on ragonse shest

3. The weight of each responsa is indicatud above the rosponse alternatives to each quastion.

4. Sum the rosponse welghts and record in the table below.

5. Record the number of quest lons answarad by the informant.

6. Olvide the sum of the resoonse walghts by the number of questions answered.

7. Record the result of the division (step 6) as the Waightad scora.

\begin{tabular}{|c|c|c|c|c|c|c|c|c|c|}
\hline Hos & Act Iv & 年 & Adant & AOD/W & Thres & Inten & mood & $01 s t 5$ & Pers \\
\hline 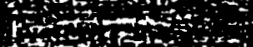 & & & & & & & & & \\
\hline 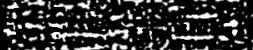 & & 46 & & & & & & & \\
\hline Hedino & & 20 & & & . & & & & \\
\hline
\end{tabular}

Regoonse glernat lves'

\begin{tabular}{|c|c|c|c|c|c|c|}
\hline 1 & 2 & 3 & 4 & 5 & 6 & 7 \\
\hline $\begin{array}{l}\text { Hardly } \\
\text { ever or } \\
\text { never }\end{array}$ & $\begin{array}{l}\text { Inrge- } \\
\text { quantly }\end{array}$ & $\begin{array}{l}\text { Onca } \ln \\
\text { a whilla }\end{array}$ & $\begin{array}{l}\text { Some- } \\
\text { times }\end{array}$ & Cften & $\begin{array}{l}\text { Vezy } \\
\text { of } t \text { an }\end{array}$ & $\begin{array}{l}\text { Almost } \\
\text { alwaya } \\
\text { aldays }\end{array}$ \\
\hline
\end{tabular}




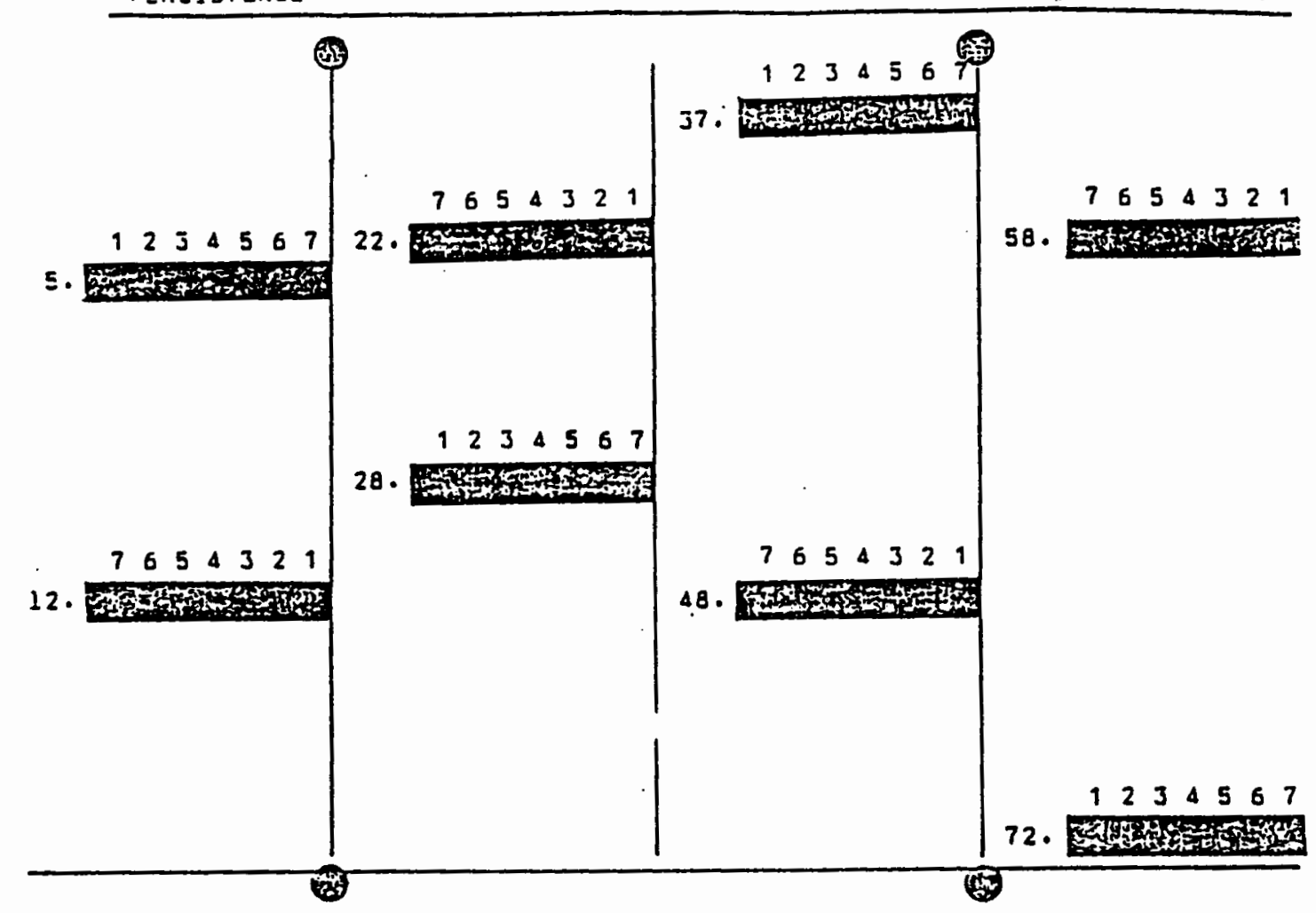

TEMPLATE \& SCOAIMC INSTRUCTIONS

1. Carefully cut put the darkened areas in the templata.

2. The round holes are for cantaring tha template over the $(\chi)$ s on response sinae

3. The Helght of each response is Indlcated above the cesponse alternatives to each question.

4. Sum the response waights and recozd lin the table balow.

5. Record the number of questions answered by tha informant.

5. Oivide tha suin of the resoonse welghta by the number of questions ansuresd.

7. Record tire result of the division (step 6) as the welghted 5core.

\begin{tabular}{|c|c|c|c|c|c|c|c|c|}
\hline S & Act 1v & Rhyth & Adapt & ADo/W & Thres & Inten & Mood & D1st I G \\
\hline $4 y^{2}=$ & & & & & & & & He \\
\hline 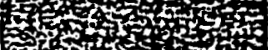 & & - & & & & & & $\cos x$ \\
\hline (2) & & & & & & & & \\
\hline
\end{tabular}

Resoonse alteinat Leg:

\begin{tabular}{|c|c|c|c|c|c|c|}
\hline 1 & 2 & 3 & 4 & 5 & 6 & 7 \\
\hline $\begin{array}{l}\text { lardly } \\
\text { dues os } \\
\text { lover }\end{array}$ & $\begin{array}{l}\text { Infre- } \\
\text { quent }=1 y\end{array}$ & $\begin{array}{l}\text { Onca in } \\
\text { e whlla }\end{array}$ & $\begin{array}{l}\text { Some- } \\
t \lim \theta 5\end{array}$ & orten & $\begin{array}{l}\text { Very } \\
\text { oftan }\end{array}$ & $\begin{array}{l}\text { Almost } \\
\text { always } \\
\text { always }\end{array}$ \\
\hline
\end{tabular}




\section{APPENDIX D}

SUBJECT DATA 
PARENT TEMPERAMENT QUESTIONNAIRE FOR CHILDREN

NORMAL (N)

\begin{tabular}{||l|l|l|l|l|l|l|l|l|l||}
\hline & $\mathrm{A}$ & $\mathrm{R}$ & $\mathrm{AD}$ & $\mathrm{A}-\mathrm{W}$ & $\mathrm{T}$ & $\mathrm{I}$ & $\mathrm{M}$ & $\mathrm{D}$ & $\mathrm{A} / \mathrm{P}$ \\
\hline 4 & 3.5 & 4.9 & 5.3 & 4.6 & 4.4 & 3.1 & 4.8 & 4.6 & 4.9 \\
9 & 4.9 & 3.7 & 6.0 & 6.1 & 3.9 & 3.9 & 6.1 & 3.9 & 4.4 \\
14 & 3.5 & 4.6 & 6.5 & 5.4 & 4.6 & 2.6 & 5.2 & 6.0 & 5.1 \\
27 & 5.38 & 4.88 & 5.0 & 5.75 & 4.13 & 4.0 & 5.38 & 4.13 & 4.25 \\
32 & 3.8 & 4.9 & 4.1 & 4.0 & 1.6 & 2.9 & 3.1 & 4.5 & 4.0 \\
36 & 2.4 & 5.1 & 5.1 & 3.8 & 3.3 & 2.5 & 4.4 & 5.3 & 4.0 \\
40 & 3.3 & 5.1 & 6.3 & 4.9 & 2.8 & 3.0 & 5.5 & 4.9 & 3.6 \\
50 & 4.1 & 5.0 & 5.3 & 4.5 & 3.0 & 4.3 & 4.3 & 4.9 & 4.8 \\
51 & 4.0 & 6.1 & 6.1 & 4.6 & 3.4 & 2.3 & 5.1 & 5.5 & 3.6 \\
58 & 4.25 & 4.63 & 6.0 & 4.63 & 3.0 & 3.13 & 4.88 & 4.88 & 4.38 \\
59 & 3.9 & 4.3 & 5.4 & 4.5 & 4.5 & 3.0 & 5.5 & 4.9 & 4.1 \\
63 & 4.3 & 4.5 & 4.9 & 5.5 & 3.5 & 2.5 & 4.3 & 4.0 & 3.5 \\
72 & 5.6 & 4.1 & 4.3 & 4.4 & 4.3 & 5.0 & 4.0 & 4.3 & 4.0 \\
78 & 3.9 & 5.8 & 7.0 & 6.6 & 3.1 & 2.8 & 5.4 & 6.0 & 4.3 \\
81 & 4.5 & 3.8 & 5.1 & 5.6 & 3.4 & 3.0 & 5.6 & 5.0 & 4.0 \\
95 & 3.9 & 5.9 & 5.3 & 4.5 & 3.1 & 4.6 & 4.8 & 4.8 & 4.4 \\
113 & 3.6 & 5.0 & 5.0 & 3.6 & 1.8 & 3.0 & 4.8 & 5.5 & 3.6 \\
129 & 3.8 & 4.1 & 6.4 & 3.5 & 2.8 & 2.8 & 6.1 & 6.3 & 3.9 \\
130 & 3.8 & 4.8 & 5.5 & 3.0 & 4.1 & 4.3 & 5.0 & 4.8 & 3.4 \\
131 & 5.4 & 5.5 & 4.3 & 4.4 & 4.0 & 3.4 & 5.4 & 4.1 & 4.9 \\
132 & 4.0 & 6.0 & 6.0 & 4.0 & 3.4 & 4.0 & 5.1 & 5.1 & 4.4 \\
133 & 2.6 & 3.7 & 5.0 & 3.0 & 3.4 & 2.4 & 5.4 & 4.6 & 4.4 \\
138 & 3.6 & 3.9 & 6.0 & 3.0 & 4.0 & 2.6 & 5.0 & 5.3 & 3.5 \\
139 & 3.1 & 3.7 & 5.1 & 4.9 & 3.5 & 3.7 & 4.7 & 5.5 & 4.1 \\
141 & 3.3 & 4.9 & 5.1 & 4.8 & 3.5 & 4.0 & 5.3 & 3.8 & 5.0 \\
144 & 4.13 & 6.25 & 5.5 & 4.63 & 3.5 & 4.88 & 5.5 & 3.5 & 4.38 \\
150 & 4.1 & 5.5 & 6.0 & 4.9 & 3.4 & 3.9 & 5.2 & 4.6 & 3.7 \\
\hline$M$ & 3.95 & 4.83 & 5.47 & 4.56 & 3.46 & 3.39 & 5.03 & 4.84 & 4.17 \\
\hline$S D$ & .76 & .77 & .71 & .91 & .72 & .79 & .64 & .70 & .49 \\
\hline & & & & & & & & & \\
\hline
\end{tabular}


PARENT TEMPERAMENT QUESTIONNAIRE FOR CHILDREN

SLOW EXPRESSIVE LANGUAGE DEVELOPMENT (SELD)

\begin{tabular}{||c|c|c|c|c|c|c|c|c|c||}
\hline & $\mathrm{A}$ & $\mathrm{R}$ & $\mathrm{AD}$ & $\mathrm{A}-\mathrm{W}$ & $\mathrm{T}$ & $\mathrm{I}$ & $\mathrm{M}$ & $\mathrm{D}$ & $\mathrm{A} / \mathrm{P}$ \\
\hline 6 & 6.7 & 5.5 & 4.4 & 3.4 & 3.5 & 3.9 & 5.7 & 4.6 & 2.5 \\
7 & 2.6 & 5.8 & 4.3 & 3.4 & 5.0 & 6.5 & 3.0 & 2.3 & 5.3 \\
12 & 4.1 & 5.8 & 5.0 & 4.4 & 3.3 & 3.8 & 5.3 & 4.8 & 4.9 \\
15 & 3.6 & 6.5 & 4.8 & 3.8 & 3.6 & 4.6 & 4.9 & 4.6 & 3.1 \\
19 & 5.0 & 6.0 & 5.8 & 4.3 & 2.8 & 3.4 & 5.5 & 5.0 & 4.1 \\
26 & 4.2 & 4.0 & 5.2 & 4.5 & 3.5 & 3.0 & 4.9 & 5.1 & 3.6 \\
29 & 6.0 & 5.3 & 5.3 & 4.6 & 1.3 & 4.1 & 4.4 & 4.1 & 5.1 \\
39 & 3.1 & 4.6 & 4.5 & 3.9 & 3.1 & 3.8 & 4.6 & 4.0 & 4.0 \\
41 & 3.6 & 4.8 & 6.3 & 5.3 & 1.6 & 3.3 & 5.3 & 5.8 & 4.1 \\
53 & 3.5 & 5.5 & 6.0 & 5.8 & 3.0 & 3.6 & 6.1 & 6.8 & 4.4 \\
55 & 4.6 & 6.6 & 5.7 & 5.9 & 2.0 & 5.2 & 5.5 & 4.7 & 4.7 \\
57 & 3.8 & 4.4 & 5.1 & 3.3 & 3.5 & 4.0 & 5.3 & 4.9 & 4.8 \\
60 & 2.8 & 4.9 & 5.9 & 4.1 & 3.7 & 3.9 & 5.8 & 5.8 & 4.3 \\
84 & 3.6 & 6.3 & 4.6 & 3.5 & 3.0 & 2.5 & 5.1 & 5.3 & 4.5 \\
85 & 4.0 & 5.3 & 4.1 & 2.4 & 2.9 & 5.5 & 4.9 & 4.5 & 4.6 \\
86 & 3.1 & 2.8 & 6.6 & 4.1 & 3.0 & 4.9 & 5.5 & 5.0 & 3.8 \\
87 & 4.5 & 5.75 & 5.0 & 5.63 & 3.5 & 3.13 & 6.0 & 5.88 & 4.13 \\
92 & 3.9 & 4.9 & 5.3 & 3.0 & 2.8 & 4.3 & 5.7 & 4.6 & 3.8 \\
93 & 2.7 & 4.0 & 5.7 & 4.6 & 3.0 & 3.2 & 5.6 & 5.5 & 3.4 \\
94 & 4.4 & 5.4 & 5.1 & 3.9 & 3.6 & 2.9 & 7.0 & 5.9 & 4.1 \\
97 & 3.8 & 4.3 & 4.6 & 4.9 & 2.6 & 4.0 & 4.6 & 3.3 & 4.4 \\
98 & 3.9 & 4.9 & 4.3 & 2.5 & 3.0 & 5.5 & 5.3 & 4.0 & 4.9 \\
100 & 2.6 & 4.5 & 5.4 & 4.1 & 3.6 & 3.6 & 4.8 & 5.0 & 3.5 \\
103 & 3.8 & 5.8 & 4.0 & 4.0 & 4.0 & 3.8 & 4.4 & 4.1 & 3.4 \\
105 & 4.3 & 6.4 & 5.8 & 4.8 & 4.6 & 4.0 & 4.5 & 5.3 & 3.6 \\
107 & 2.9 & 5.5 & 5.5 & 3.5 & 2.8 & 3.6 & 4.1 & 5.5 & 3.1 \\
109 & 4.3 & 5.4 & 3.1 & 3.6 & 3.3 & 5.6 & 3.5 & 2.6 & 3.9 \\
111 & 4.0 & 4.3 & 3.5 & 3.1 & 2.8 & 5.8 & 3.9 & 3.5 & 4.8 \\
114 & 4.1 & 4.4 & 5.6 & 4.8 & 2.6 & 3.6 & 5.1 & 5.6 & 4.1 \\
116 & 4.0 & 4.5 & 6.1 & 4.8 & 3.1 & 3.4 & 5.3 & 5.2 & 3.3 \\
119 & 4.5 & 4.7 & 4.3 & 2.7 & 2.8 & 4.3 & 5.2 & 4.1 & 3.7 \\
122 & 3.9 & 5.0 & 5.6 & 3.6 & 3.1 & 3.5 & 5.0 & 4.1 & 3.8 \\
142 & 3.6 & 5.6 & 5.0 & 4.6 & 2.8 & 5.1 & 5.1 & 5.4 & 4.3 \\
\hline$M$ & 3.92 & 5.13 & 5.08 & 4.09 & 3.12 & 4.10 & 5.06 & 4.75 & 4.06 \\
\hline$S D$ & .87 & .84 & .81 & .90 & .71 & .94 & .77 & .97 & .64 \\
\hline
\end{tabular}


KEY:

A $=$ Activity Level

$\mathrm{R}=$ Rhythmicity

$\mathrm{AD}=$ Adaptability

$\mathrm{A}-\mathrm{W}=$ Approach-Withdrawal

$\mathrm{T}=\quad$ Threshold of Responsiveness

I = Intensity of Reaction

$\mathbf{M}=\operatorname{Mood}$

D = Distractibility

$\mathrm{A} / \mathrm{P}=\quad$ Attention Span/Persistence 